\title{
هيئة التحرير
}

رئيس مجلس الإدارة و عميد الكلية

$$
\text { أ.د. جودة محمد مبرو ك }
$$

رئيس التحرير ووكيل الكلية للدراسات العليا والبحوث

أ.د. رمضان محمد عبد النبى عامر

$$
\text { نائب رئيس التحرير }
$$

أ.م.د. مها أحمد إبراهيم

مدير التحرير

أ.م.د. منال سيد محمد

$$
\text { سكرتير التحرير }
$$

أ. محمد ربيع عبد الظاهر

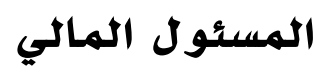

أ. محممود جابر محمدين 
2.20

\section{الهيئة الاستشارية}

قسم علوم المعلومات

قسم ملوم المعلومات

قسم الفلسفة

قسم علم النفس

قسيم علم النفس

قسم الاجتماع

قسم الاجتماع

قسم اللغة العربية

قسم اللغة العربية

قسم اللغة العربية

قسم اللغة العربية

قسم اللغة العربية

قسم اللغة العربية

قسم اللغة العربية

قسيم الجغر افيا

قسيم الجغر افيا

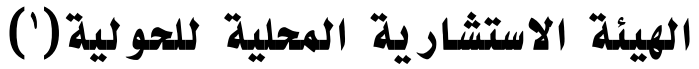
أ.د. أحمد محمود عبد الوهاب المصري

ا.د.محمد جلال سيد غندور

ا.د. عبير عبد الغفار

أ.د.هشام عبد الحميد تهامي

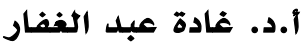

ا.د.طلعت إبر اهيم لطفي

ا.د..مصطفى خلف عبد الجواد

أ.د.أحمل عبد العزيز دراج

ا.د.السيد إبر اهييم محمد

أ.د جودة مبروك محمد مبروك

أ.د.صلاح الدين حسانين

ا.د.محرووس محمد إبراهيم

ا.د. رمضان احمد عبد النبي

ا.د.دممد خليل نصر الله

ا.د.. محممد عبد العزيز يوسف

ا.د. . محمد فوزي الحمد عطا سليمان

(' ) تم ترتيب الأسماء استناد لتصنيف ديوى للمعرفة البشرية ، ثم هجائيًا بالأسماء 


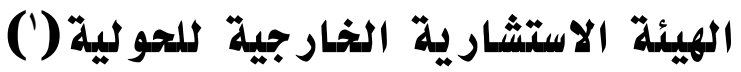

أستاذ المكتبات والمعلومات .جامعة القاهرة

أستاذ المكتبات والمعلومات . ججامعة القاهرة

أستاذ المكتبات و المعلومات .جامعة القاهرة

أستاذ المكتبات و المعلومات . جامعة القاهرة

أستاذ المكتبات و المعلومات .جامعة القاهرة

أستاذ الفلسفة .جامعة القاهرة

ا.د مصطفي حسن محمد النشار استاذ الفلسفة .جامعة القاهرة

أستاذ الفلسفة.جامعة حلوان

ا.د مني أحمد محمد أبو زيل

أ.د. عبد المنعم ثحاتة محمود أستاذ علم النفس.جامعة المنوفية

ا..د. طه أحمل حسانين المستكاوي أستاذ علم النفس • جامعة أسيوط أستاذ اللغويات والترجمة.جامعة سوهاج

أستاذ الأدب والترجمة.جامعة القاهرة

أستاذ الأدب العربي •جامعة عين ثمس

أستاذ الأدب العربي •جامعة المنيا

أستاذ الجغرافيا الطبيعية. جامعة سوهاج

أستاذ الجغرافيا.جامعة القاهرة

أستاذ التاريخ • جامعة/لأزهر

أستاذ التاريخ. جامعةالمنصورة

أستاذ التاريخ.جامعةالأزهر
ا.د. بهاء الدين محممد مزيل

ا ا.د. محمد عناني .

ا.د. يوسف حسن ثوفل

أ.د. أحمد جودة السعدني

ا.د. كريم مصلح صلاح

ا.د. شحماتة سيد أحمد

ا ا.د.عفاف صابرة

أ.د.إبراهيم عبد المهيد

| (1.د.عبد المنعم شحاته

(' ) تم تر تيب الأسماء استنادً لتصنيف ديوى للمعر فة البشرية ، ثم هجائيًا بالأسماء 
حولية كلية الآداب جامعة بني سويف حولية علمية محكمة تصسـدر

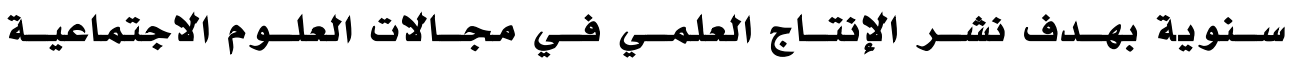

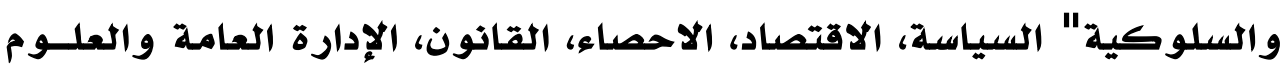
العسـكرية، الخدمــة الاجتماعيـة والجمعيـات الأهليــة، التعلـيم، النقــل

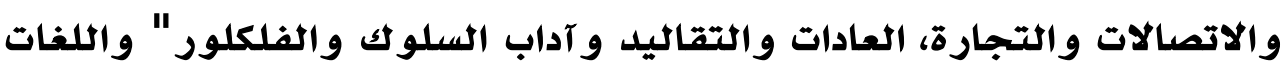

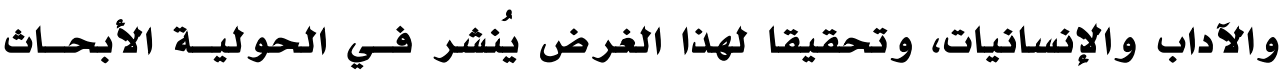

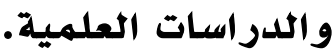

وتتضمن الحولية بجانب البحوث التي يتقرر نشرها، عروضًا للكتب

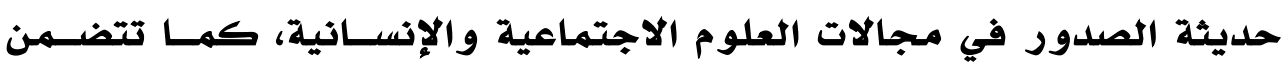

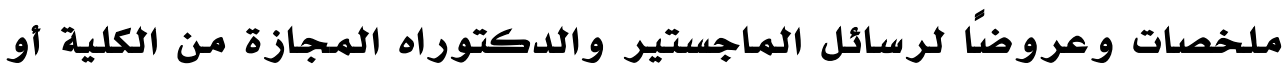

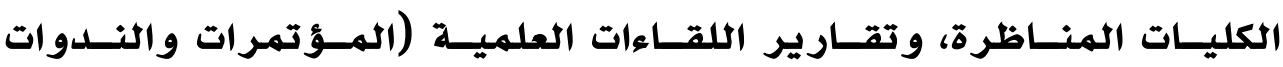
والحلقات العلمية).

وتراعي هيئة تحرير الحولية إتباع قواعد التحكسيم العلمـي التـي

يجرى العمل على أساسها في المجالات العلمية وذلك لتحديد صلاحية ما يرد إليها من مقالات وبحوث. هذا وينشر كل بحث بعد موافقة كتابيـة على نشر البحث من محكمين على الأقل. 
قواعد النشر بالحولية:

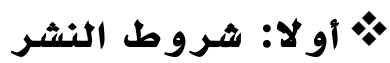
ا- ترحب الحولية بنشر البحسوث والدراســات العلميــة التـي تتسـم بالأصـالة والجدة، بإحدى اللغتين العربية أو الإنجليزية، شريطة أن يرفق بالأبحساث

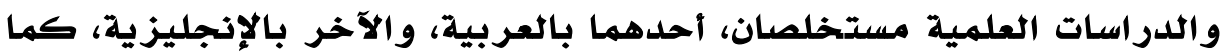
تنشر التقرير السنوي عن انجازات الكلية، وكذا لمسة وفاء (حيث يتم البدء البهاء بنشر رسائل الماجستير والدكتوراة لأعضاء هيئة التدريس الذين توفـاهم الدماء

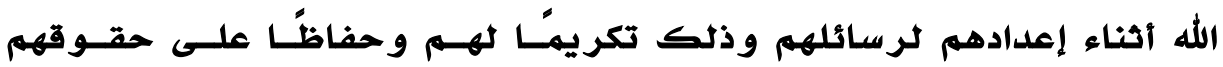

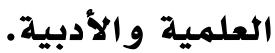

r- كما ترحب الحولية بنشر الترجمات، وملخصات الرسائل الجامعية المجازة من الكلية أو الكليات المناظرة، وتقارير المــؤتمرات والنسـدوات والحلقــات اللدراسية، وعروض الكتب حديثة الصدور في مجـالات العلـوم الاجتماعيـة

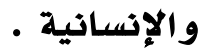

ץ- لا يتم نشر الدراسات التي سبق نشرها باي صورة من صور النشر، أو قدمت

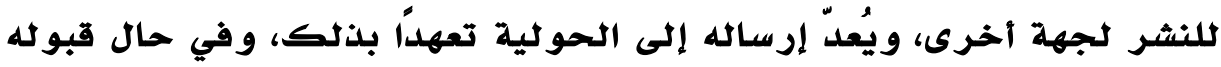
للنشر في الحولية لا يسمح للباحث بنشره في مكان آخر. ع- يلتزم الباحث بعدم تقديم الدراسة المقدمة للنشر إلـي أي مجلــة أخـري، وذلك حتي يتم إعلامه بنتيجة التحكيم. ه- يتحمل الباحث تكاليف تحكيم البحث سواء قُبل للنشر أم لم يُقبل. ז- لن ينظر إلى الأبحاث التي لا تتفق وشروط وقواعد النشـر بالحوليـة ، أو ترد ناقصة لملخص البحث في أي من اللغتين. v - لا ترد أصول الأعمال المقدمة للحولية سواء قُبلت للنشر أم لم تُقبل. 
ا- يقدم الباحث نسختين ورقيتين من البحث علسى ورق (A4) بالإضـافة إلىى نسخة إلكترونية على CD أو عبر البريد الإلكتروني.

ب- يلتزم الباحث بتقديم سيرة ذاتية مختصرة تتضمن: الاسم كاملا، واللدجـة العلمية، وجهة العمل، والعنوان البريدي، والبريد الإلكتروني، وأرقام الهواتف

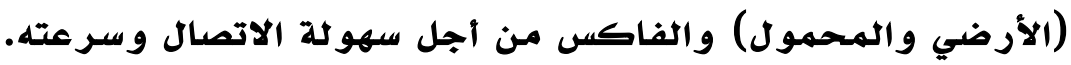

r- تقوم هيئة التحريـر بـالقراءة الأوليـة للبحــوث العلميـة المقدمــة للنشـر بالحولية للتأكد من توافر مقومات البحث العلمي، وترسل بعد ذلك إلىى المحكمين، مع مر اعاة ما يلي:

• تختار هيئة التحرير شخصاً من جهـة علميـة مختلفـة يعهــ إليـه بمهمـة التحكيم، على أن يكون متخصص في مجال البحث، ويفضل أن يكون بلدجة أستاذ أو أستاذ مساعد.

يرسل العمل العلمي إلى المحكمين بصفة سرية بلدون ذكر اسم الباحث أو ما يلل على شخصيته، ويرفق مـع العمل العلمي المراد تحكيمه استمارة تقويم تضم قائمة بالمعايير التي على ضوثها يتم تقويم العمل العلمي. يتولى أعضاء هيئة التحرير متابعة إجراءات التعديل والتحقق مـن اسـتيفاء التعديلات المطلوبة قبل ثشر العمل العلمي. • يتم إبلاغ جميع الباحثين بقرار صلاحية بحوثهم للنشر من عدمه. • ينشر العمل العلمي إذا اجتاز التحكيم وفق الضوابط العلمية المتعارف عليها واستوفى قواعد وشروط النشر بالحولية ، ويعتذر عن نشره في حالة عدم تحقق ذلك. 
" يكتفي بالإجازة من قبل اهنين من أعضاء هيئة التحرير لنشر مراجعات الكتب والرسائل الجامعية وتقارير اللقاءات العلمية.

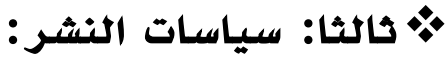

ا- تعطى الأولوية في النشر للبحوث والتقارير حسب الأسبقية الزمنية للورود إلى هيئة تحرير الحولية، وذلك بعل إجازتها من قبل المحكمـين، ووفقـا للاعتبارات العلمية والفنية التي تراها هيئة التحرير. ץ- يتم ترتيب الأبحاث داخل العلد موضوعياً وفق خطة تصنيف ديوي العشري العالمية المستخلدمة في تصنيف المعرفـة فـي المكتبـات، وفـي الموضـوع الواحل يراعى الترتيب وفق الدرجة العلمية لصاحب العمل، دم هجائيا. ب- ير اعى الترتيب التالي في أجزاء البحث: صفحة العنوان، المستخلص باللغـة العربية، المستخلص باللغة الإنجليزية، الكلمات اللدالة، المقلمة المنهجيـة، النتائج ومناقشتها، المراجع، الأثكال والجداول و الملاحق. يسجل على صفحة العنوان: عنوان البحث في منتصف الصفحة، واسم الباحث

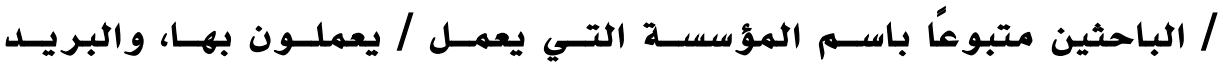
الإلكترو ني الخخاص به / بهم.

يراعى أن يكون المستخلص في حلدود ،10 كلمـة، وخـال مـن الاختصسارات والمراجع، ويشير بوضوح إلى أهلاف البحث ومنهجيته وأهم نتائجه. يقصل بالكلمات الدالة: المصطلحات الرئيسة التي وردت في مستن البحسث أو المباحث الفرعية التي تم تناو لها.

يراعى في المقلمة أن تقدم خلفية كافية عـن الموضـوع وان يوضـح بهـا المــهجج المتبــع وأدوات جمــع البيانـات وإجــراءات اللدراسـة و التحلـيلات الإحصائية المستخدمة، إن وجدت، والدراسات السابقة، والمثيلة. 
بعد المقدمة المنهجية يتم عرض النتاتج التي توصل إليها الباحث، يلي ذلك مناقشة هذه النتائج ومناقشة صحة فرضيات الدراسة ومدى ارتباط النتائج بالأعمال المنشورة التي تناولت نفس الموضوع.

ير اعى عدم وضع الجداول الكبيرة والأثكال التوضيحية والخر ائط الكبيـرة في متن البحث بل توضع في نهايته حتى يتمكن المراجعون من التحكم في حجمها وفق حجم صفحة الحولية ، أما الجداول والأثكال التي توضع في سي متن البحث فيجب أن يكون كل منها في صفحة مستقلة على أن يوضع رقم الجدول وعنواثه أعلاه، ورقم الشكل وعنواثه أدناه. تسجل المراجع على النحو التالي:

\section{في حالة الكتب:}

اسم المؤلف (سنة النشر) ). عنوان الكتاب.- رقــم الطبعـة.- مكسـان النشـر، اسـم

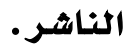

\section{في حالة مقالات اللدوريات:}

اسم المؤلف (سنة النشر). عنوان المقال.- عنوان الدورية.- رقم المجلد (رقـم العدد)، الصفحات التي يشغلها المقال. في حالة المصلر الإلكتروني على الويب:

اسم المؤلف (تاريخ الإتاحة على الموقع). عنوان المصدر الإلكتروني. متاح على الرابط: >يوضع الرابط> تاريخ الاطلاع. خ رابعا: حقوق النشر

ا- يُمنـح كل باحث إفادة بقبول بحثه للنشـر بعـد إتمـام كافــة التصـويبات والتعديلات المطلوبة بعد التحكيم. 
(2) (P)

ץ- يُمنح كل باحث عشر مستلات من بحثه المنشور، بالإضافة إلى ثسخة واحلة من الهحولية

خامسا: رسوم النشر

بعد قبول البحث أو الدراسة ثلنشر يسهم الباحث في تكاليف طبامة بحثه ونشره ملى النحو التالي:

\begin{tabular}{|c|c|c|c|c|}
\hline \multicolumn{2}{|r|}{ تكلفة الصفحة } & \multirow[b]{2}{*}{ رسم تحكيم البحث } & \multirow[b]{2}{*}{ الجهة التابع لها الباحث } & \multirow[b]{2}{*}{ ค } \\
\hline العـــــد الدخاص & العدد الأساسى & & & \\
\hline ع جنيهــات & |r منيه & 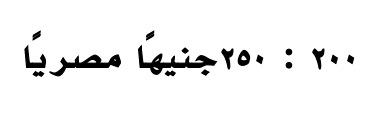 & كلية الآداب ببني سويف & 1 \\
\hline r منيهــات & 10 منيه & r.. : r.. . جنيها مصريًا & أعضـاء هيئـــة التــلدريس & $r$ \\
\hline •عنيهُ مصرَا & rجنيها مصريًا & Pro. : r.. & أعضــاء هيئـــة التـلدريس & $r$ \\
\hline 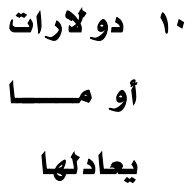 & ه دو لارات أو مـا & ״.. دولار أو ما يعادلها & أعضاء هيئة التدريس من & $\varepsilon$ \\
\hline
\end{tabular}

ملحوظة : تسترد مبالغ النشر في حالة مدم قبول البحث للنشر، بعد خصم قيمة التحكيم و الهر اسلة (YOP جنيهاً) ٪ سادساً :الهتر اكات اثحو لية قيمة الاثتراك السنوي للعدد الرئيسي كما يلي : 
(Q)

من داخل جمهورية مصر العربية : للافراد יه ج.م

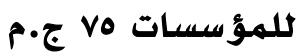

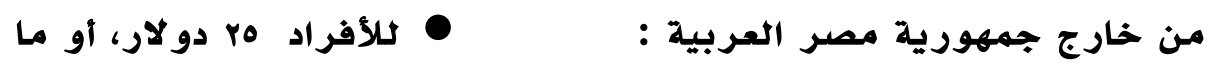
يعادلها

†للمؤسسات •0 دو لار، أو ما

يعادثها

国

ترسل جميع المر اسلات باسم رثيس تحريـر الحوليـة علـى العنــوان البريـدي التالي:

• جمهورية مصر العربية- محافظة بني سويف- كلية الآداب- رئيس تحرير حولية كلية الآداب.

-Arrrranor : أو عن طريق فاكس رقم

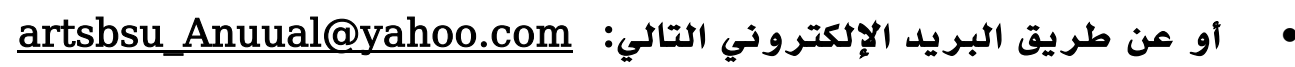




\section{كلمة التحرير}

يسر حولية كلية الآداب أن تصدر العدد الخاص لعام 19+rم باحد الأبحاث المتميزة وعنواثه" الفعل الصوفي طبيعته وتجلياته عند محمد الهد ان زكي إبراهيم" للدكتور سيد حافظ عبد الحميد بدوي مدرس الفكر العربي الحديث بكلية الآداب - جامعة بني سويف. يلور البحث حول موضوع ثديد الأهمية إذا يتعلق بتاكيد دور الفعـل

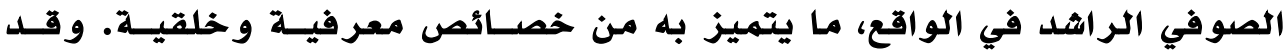
حاول البحث أن يقارب بين فلسفة الفعل والفعل الصوفي مـن خسلال التصــوف الراشد الذي يربط بين النظر والعمل، ويتسيج بالكتاب والسنة، وانتخب الباحث

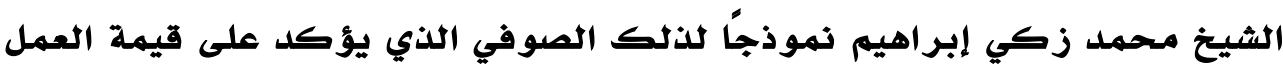
و الفعل الإنساني الصوفي و أهميته وتوظيفه في خلمة الواقع الإنساني؛ لخدمــة الوطن والأمة، وتاكيده على أن التصوف الحق تصوف إيجابي فاعل يهدف إلىى تحقيق إنسانية الإنسان حينما يربط المادي بالروحي من خلال جانب الإحسان.

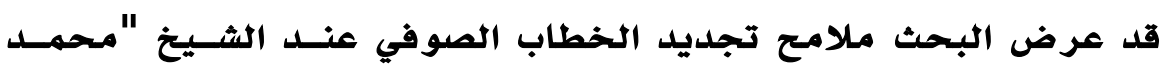

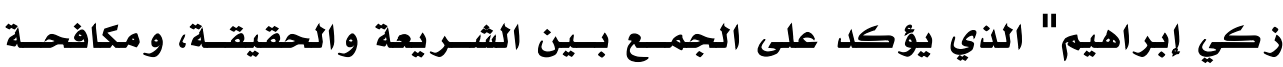

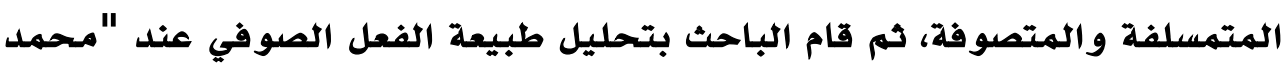

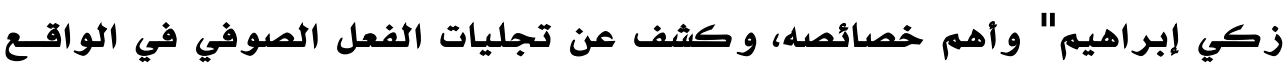
من خلال الأدوار الاجتماعية والعلمية التي قدمها الشيخ الرائد من خلال مؤسسة

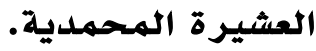

و قد انتهى البحث إلى أن الفعل في التصوف العملي عند "محمد زكـي إبراهيم"هدفه جعل رسالة الصوفي رسالة إصلاحية إنسانية تتحقق في الممارسة الحياتية بكل تجلياتها الدينية والسياسية والاجتماعية والاقتصادية والحضارية. و فى النهاية تتقدم أسرة الحولية بهذا البحث ثقة منها بانه سيكون إضـافة للمعرفة العلمية المتميزة .

هيئة التحصرير

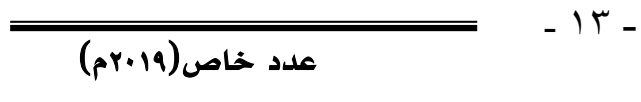




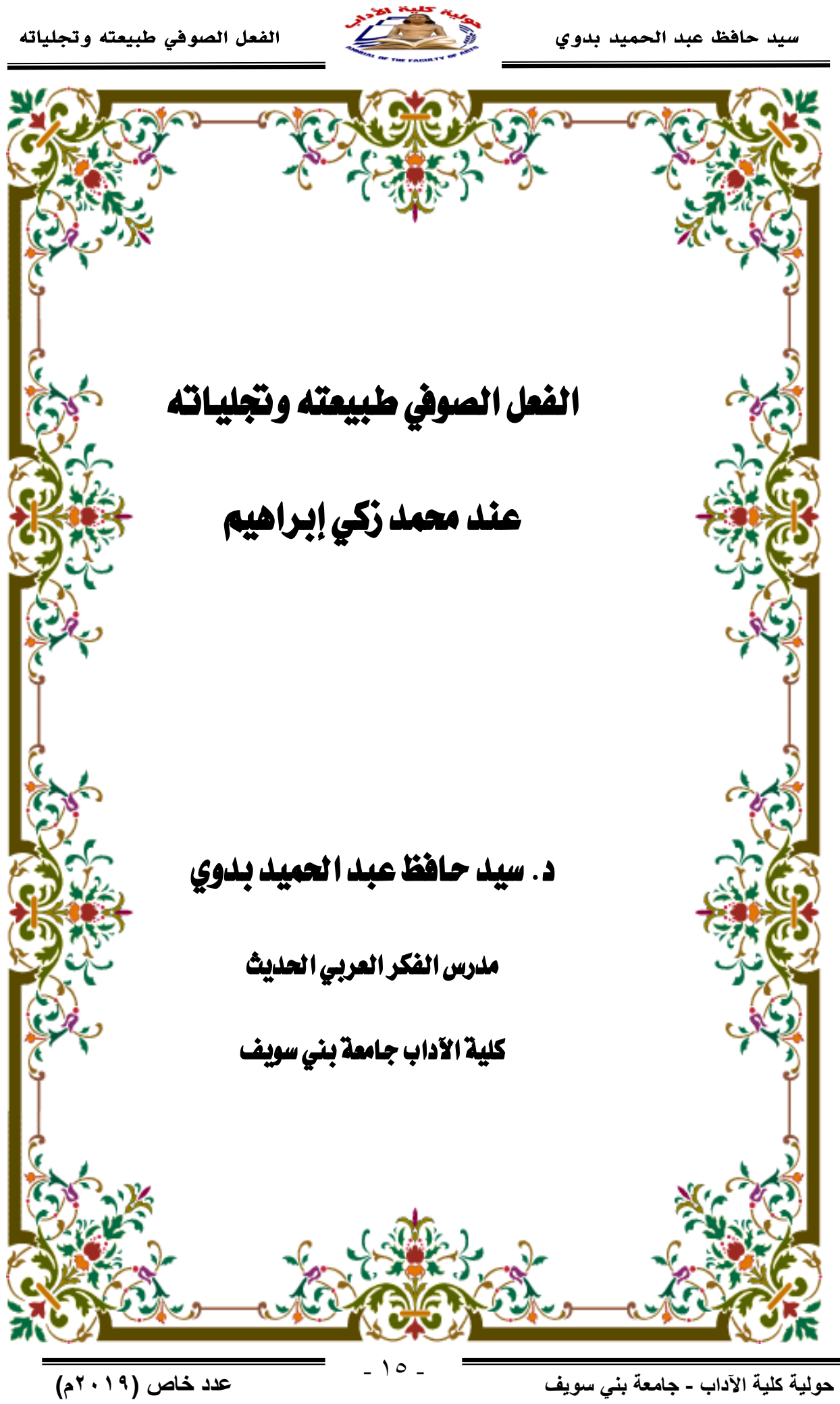


الفعل الصو في طبيعته وتجلياته

سيد حافظ عبد الحميد بدوي

عداص (19 (19)

$-17$.

حولية كلية الآداب - جامعة بني سويف 


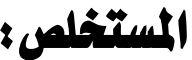

يتناول هذا البحث الفعل الصوفي (طبيعته و تجلياته) عنـــ محمـــ زكسي إبر اهيم الذي يُعدد مشرو عه الصدوفي واحد من أهم المشروعات الصوفية في الفكر العربي والإسـلامي المعاصر، وذذك من خلال مقاربته ودراسته من منظور فلسفة الفعل.

وقد طرح البحث عدد من التساؤلات تمثلت في: هل هنـالك نقـاط التقـاء بين التصوف وفلسفة الفعلى و مـا هي مـلامح التجديد الصوفي عنـد محمـــ زكسي

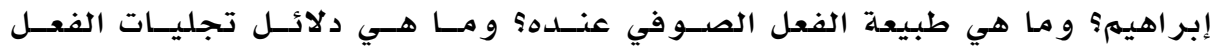
الصو في؟ وقد حاول البـحث أن يجيب على هذه التسـاؤ لات مـ خلال الوقـوف علـى العلاقة بين التصوف العملي و فلسفة الفعل، ثم التعريف بالشيخ الر ائد، وتكوينسه العلمي و الصوفي و الفكري، وكشف ملامتح تجديد خطابه الصوفي، و تحليل طبيعة الفعل الصوفي عنده، الذي يبـدأ من الداخل لبنـاء الإنســان الربـاني، ويتجـهـ نحـو إصـلاح الواقع، كما عرض البحث لتجليات الفعل الصوفي في الواقع وأوضح كيف عمل محمد زكي إبر اهيم على الربط بين النظر و العمل. الكلهـات اللدادة: الفعل الصـوفي - فلسفة الفعلـ التصـوف العملي- حمح زكي إبر اهيم

\section{Abstract}

This research deals with the nature and manifestations of the Sufi action in Muhammad Zaki Ibrahim's works. Ibrahim meant his Sufi project to be one of the most important Sufi projects in contemporary Arab and Islamic thought، through his study from the perspective of the philosophy of action. The research raises a number of questions، like: is there a relationship between Sufism and the philosophy of action?

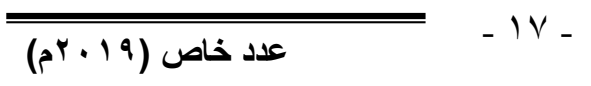


What are the features of Sufi innovation in the works of Muhammad Zaki Ibrahim? What is the nature of the Sufi act in his works? What are the signs of the manifestations of the Sufi act?

The researcher tries to answer these questions by examining the relationship between practical Sufism and the philosophy of action، then introduces the pioneering Sheikh، his scientific mystical and intellectual formation، revealing the features of the innovation in his Sufi discourse' and analyzing the nature of his Sufi action' which starts from within the self to build the divine person ، and turns Towards reforming reality. The researcher presents the manifestations of the Sufi act in reality and explains how Muhammad Zaki Ibrahim worked on the link between theory and action.

Descriptors:Sufi verb - Philosophy of verb - Practical Sufism - Muhammad Zaki Ibrahim
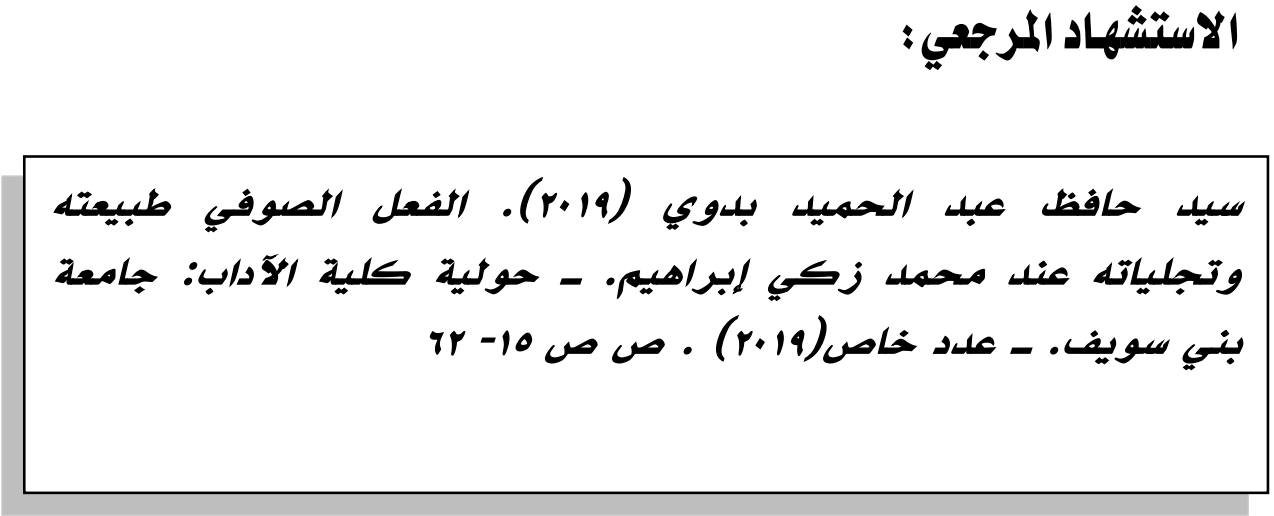


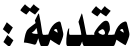

تميز الفكر العربي والإســلامي الحسلديث فـي عصـر النهضـة بالصبغة العملية ومعالجة مشكلات الواقع ومحاولة تحويل الخطابات النهضوية إلى مشروعات وبر امج عمـل، وقـلد حسـاول أصسحاب تلــك الخطابات التغلب على المعوقات التي اعتر ضــتهم وتجاوزهــا. ومنــذ النصف الثاني من القرن العشرين خفتت تلك الصبغة، و أصبحنا غالبًا أمام خطابات مستغرقة في التحليل لا نجد لها ماصلدقات فـي الواقـع المعاش وخاصة الخطابات الفلسفية العقلانية، لكننا لم نعسلم وجـود هذه الصبغة في واحد من أهم المشروعات الصوفية في الفكر العربي و الإسلامي المعاصر، وهو المشروع الإصلاحي الصـوفي عنــد محمـــ زكي إبراهيم، والذي حاول الباحث أن يتناوله من خلال الوقوف على طبيعة الفعل الصوفي عنده وتجلياته في الواقع. وترجع أهمية البحث في هذا الموضوع من وجهة نظر الباحث

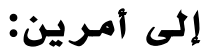

الأول: طبيعة مشروع محمد زكي إبراهيم الذي استطاع أن يجمع بين النظر والعمل، وشرع في تحقيق مشروعه الإصلاحي فـي أرض الواقع، الأمـر الذي أمكن معه مقاربتـهـه ودراسـته مـن منظــور فلسفة الفعل، إضافة إلى الاستعانة بالمنهج التحليلي والمنهج التاريخي في قراءة وعرض أفكار الشيخ الر ائد. 
الثشاني: ثلرة اللدراسات إليها التي أهتهت بهشروع محهد زكي

إبر اهيهم الصوفي مـن زاوية الدراسـات الفلسفية، فلم أجد بعد البحث إلّا دراسـة: إيهاب عبد العزيز الكومي بعنوان: الشيخ محمدل زكـي الـدين إبر اهيهم وجهوده في التصوف، رسـائة دكتـور اه، قسـهم اللغــة العربـة و الدراسـات الإسلامية، كلية التربية، جامعسة عـين شـهس V+..rم، فـي

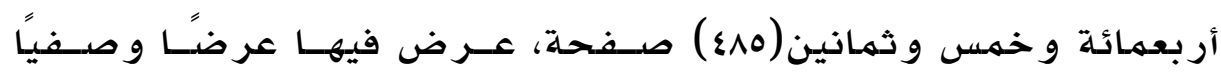
تفصيليًا لهسيرة الإمـام الر ائد وجهوده الصوفية، ودراسـة: إيهـان محهمد الهميلحي بعنوان: التصدوف الأخلاقي عند محمد زكي إبراهيهم و أثره الإصلاحي الاجتمـاعي في الحياة المعاصـرة فـي مصسر ، بحسث بهـجلـة كلية الآداب والعلوم الإنسانية، جامعة قناة السويس، عددس، البrم فـي سبـع عشرة (IV) صفحة. تنـاولت التصدوف الأخلاقي عند الإمسام الر ائسل

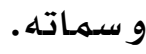

و تتمثل تسـاؤلات هذا البـحث في: هل هنـاك نقــاط التقـــاء بـــن التصوف و فلسفة الفعلو ومـا هي ملامح التجديد الصدوفي عنـد محهــد زكي إبر اهيهم و مـا هي طبيعة الفعل الصوفي عنده؟ ومسا هـي دلائسل تجليات الفعل الصووفي عنده؟ وقد حاول البـاحث أن يجيب علـى هــذه التســاؤلات مــن خـلال ل

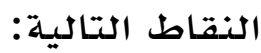
أو لاً: التصوف العملي و فلسفة الفعل: حاول من خلالها الوقوف على نقطة الالتقاء بين فلسـفة الفعـل، و الفعـل الصـوفي مسن خـلال

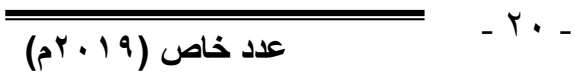
حولية كلية الآداب - جامعة بني سويف 
التصوف العملي الر اشلد الذي يؤكد علـى مســـوليـة الإنسـان و الفعـل الإنساني.

ثانياً: محمدل زكي إبر اهيهم رائد التصوف العملي الر اشد: وقف فيها على التعريف بالشيخ الر ائد، وتكوينه العلهي و الصدوفي و الفكري، وتأثره بالحرركة الإصدلاحية الصوفية الوطنية. ثالثًا: تجديد الخطاب الصدوفي: تناول مـن خلالهـا مـوقفـهـ مـن تجديد وإصلاح الخطاب الصوفي، مـن خلال تجاوز التصسوف الجـدلي، و التأكيد على التصوف العملي الر اشد، و تجديد طريقة عرض الخطاب الصو في، و مكافحة التمسلف و التمصوف. رابعًا: طبيعة الفعل الصدوفي: عالج مسن خلالهـا طبيعـة الفعـل الصدوفي الذي يبدأ مـن الداخل لبنـاء الإنسـان الفرد الرربـاني، ثـهم يتجـهـ نحو إصدلاح الواقع •

خامسيًا: تجليات الفعل الصوفي في الواقع: كشف خلالها كيف عمل مهحمد زكي إبراهيهم على الربط بين النظر والعهل وحاول ربط الفكر بـالواقع من خــلال الطريقـة الهحمهديـة، و العشـيرة الهـحمديـة و مؤسساتها الاجتمهاعية و العلميـة المتتنو عة. خاتمسة: عرض ضيها لأهم النتائج التي تـهم التوصدل مسن خـلال البـحث. 


\section{أولاً: التصوض المعلي وظلسفة الفمل:}

تتمحور فلسفة الفعل(Philosophy Of Action) حول أن

كل نظرية للفعل تتضهن نظرة أسـاسية إلـى طبيعــة الإنسـان بحيـث يهكن القول بأن الإنسان حيوان فاعل أولا، و أنه مفكر لأنه فاعل و ليس Maurice العكس (1) •ويرى الفيلسـوف الفر نسـي مـوريس بلونـدل Blondel الفكر بالحياة في الوجود(r) ) و هذا يعني أن فلسفة الفعل هي التي تهتم بـالإنسان الذي يعيش و اقعه بها يتضهنه هذا الواقع مـن مشكلات، وهـي

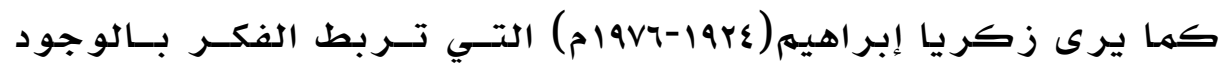
و تعنــي بهشـــلة الهصــير الإنســـاني (r) •و ذهـــبـ هنــري بر جســون Henri Bergson نحن عليه، وأننا نتيجة ما نفعل إلى حد ما(؟) و مـن ثم يمكن القول بأن فلسفة الفعل قد تجاوزت مقو لة أن "الإنسان حيوان مفكر " إلى مقولة أنه "فاعل"، و ذلك حين يعمد إلى تشـكيل الهـادة، وتغيـيـر الطبيعسة،

1) عزت قرني: الذات ونظرية الفعل، دار قباء للطباعة والنشر والتوزيع، القاهرة،

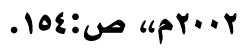
r) زكريا إبراهيم : فلسفة الفعل، رسالة مقدمة لنيل درجة الماجستير في الآداب

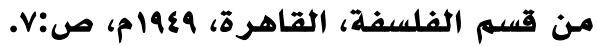

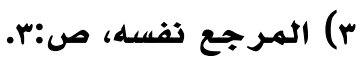
ع) هنري برجسون: التطور الخالق، ترجمة محمد محمود قاسم، المركز المرة القومي

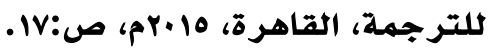

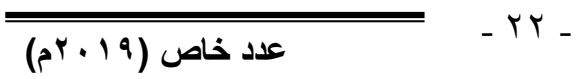


و توطيد أركان الحضسارة( ) فهي فلسفة تطبيقية، تهـدف إلـى تغيــر الواقع و التأثير فيـه، وتسعى إلى تطبيق الأفكار فـي الواقـع و إعطائهــا مضهون و اقعي، فالفعل كهما يقول موريس بلوندل:"هو نقطة تحـول في مسـار التاريخ الشـامل " أي أنه الهؤثر في مـجرى الأحسـداث الكونيـة و البشر يـة(r) (r)

وتلتقي فلسفة الفعل بالفعل الصو في مـن خلال التصوف العملي الر اشد، الذى أعلى مـرتبـة العهل إلى رتبـة معيـار صـالاح الإنسـان لـيس في الحيـاة الدنيوية فقط بل و الأخرو يـة أيضًا، فالعمل فيهــا بــرى أبـو

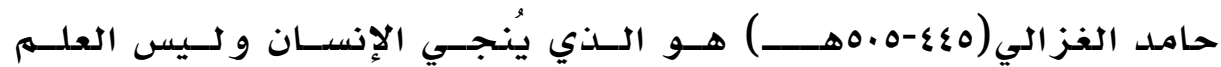
الهـجرد؛ يقول :"لا تكن من الأعمال مفلسيّا و لا مــن الأحسوال خاليّا، و تيقّن أن العلهم المهجرّد لا يـأخذ اليد.... فكذا لو قر أ رجـل مـائـة ألـف مسألة علهية وتعلهها، ولهم يعهل بها، لا تفيده إلا بالعهل....ولو قـر أت العلهم مـائة سنـة وجمعت ألف كتاب، لا تكون مستعداً لرحمهة الله تعـالى

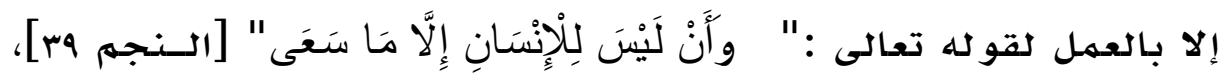

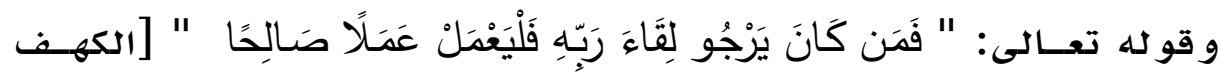
(r) $[11$.

(1) زكريا إبراهيه: مشكلة الحياة، مكتبة مصر، القاهرة، I9V|، ص :هr-هو.

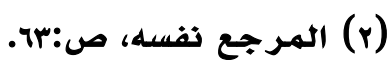
(r) أبو حامد الغزالي: أيها الولد: حققها وعلق عليها: علي محي الدين على، دار

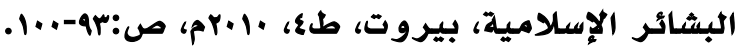
حولية كلية الآداب - جامعة بني سويف 
ويققرر التصوف العهلي أن الدخول فـي العمـل يـورِّ صــاحبـ علهًا لهم يكن يعلهـه؛ أي أن العهل يتّوصل بـه إلى العلهم، و أنهّ على قـدر إخلاص الإنسـان في العهل، يزيد علهـ، إذ تنفتح له أبواب جديـدة فـي الفهم و الهعرفة"'(1) يقول سهل بن عبد الله (ت- سیوهــ):"شكر العلــم

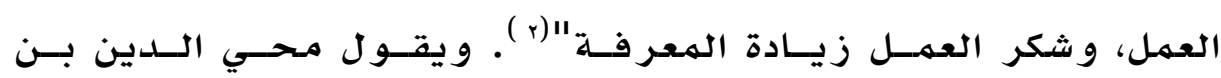

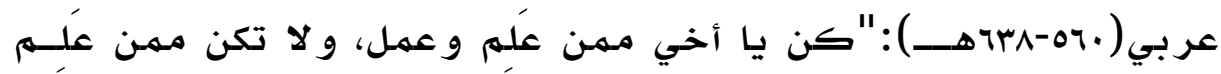

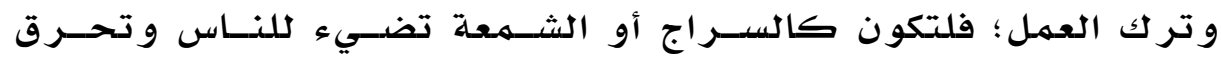

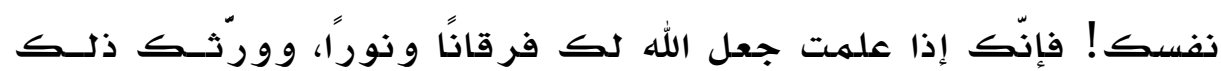
العلهم علهما آخر لهم تكن تعلهمه من العلـهم بـالله، فاجهـد أن تكـون مــن العلمهاء العاملين" ويقول : "و عليكك بـالتودد لعبـاد الله مــن الهـؤمنـين بإفشاء السلام، و إطعام الطعام، و السعي في قضاء حو ائجهم "(r ).و يقـول :"فإذا قر أت القر آنَّ فكن أنت بـالقر آنِ لهــا فـي القـر آن، واجتهــد أن

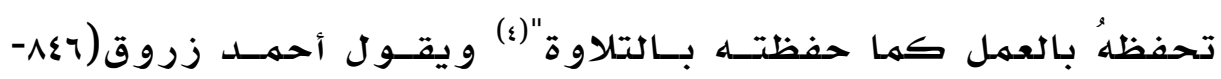

(1) طه عبد الرحمن: سؤال العمل بحث عن الأصول العملية للفكر والعلم ،

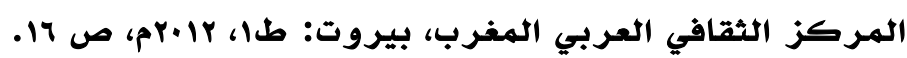

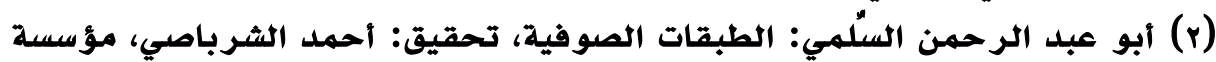

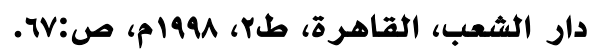

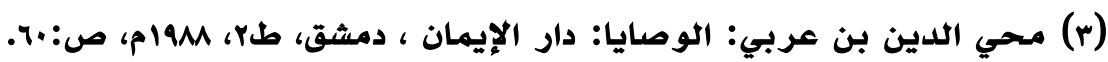

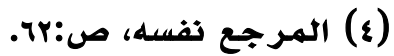

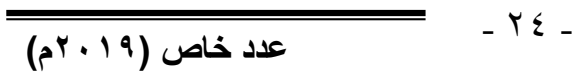


199هــ):"مـن لهم يظهر له نتيجة علهـه في عمله، فعلهـه عليـهـ لا لـه، ور بهما شههد بخر و جـه منـه" (1).

فالتصدوف العهلي يؤكل على أهميـة الفعل الإنساني في تحقيـق الوجودد. الهتهـثل في عمارة الكون مـن خلال تأكيد الفعل الصدوفي فـي الو اقع • و هكذا يكون منوطًا بتحقيق الخلافة في الأرض في رأي عبـد

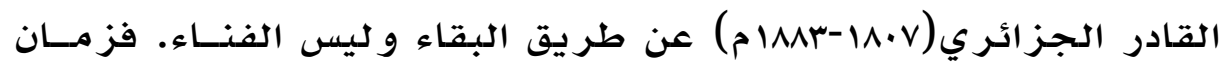
الفناء الحاصل في الدنيا يفوت مقامًا مـن الهقامسات فـي الآخـرة، لأن الفاذي يفنى عن عبوديته التي هي معرفة الله و عمارة الكون، وكل أمـر يخرج العبد عن أصلهل وحقيقته فها هو مــن الشـرف بهكــان، فالـدنيا ليست بهوطن الفناء، و إنهما دار عمل وتكليـف و مـجـاهــدة(r). فالتصــوف الر اشد يؤكد على الفـاعلية و المسئو لية الإنسانية، فالإنسـان مسئو ل عن

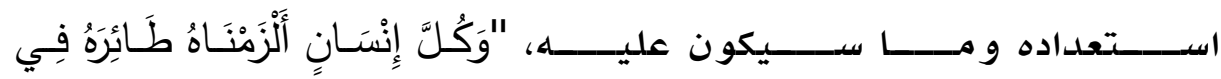
عُنُقِهِ" (الإسـر اء:با)، هذا الأمـر يؤكده الشيخ الأكبر مسحسي الـدين بــن عربي(1170-•عبام) في كاملامه عن الفعل و نسبته للإنسان، يقول :"و أي دليل أقوى على نسبـة الفعل إلى العبلد، و إضـافته إليه، و التجلي فيسـه، إذا كان من صفته كون الحق خلقه على صورته، فلو جُرد الفعل عنه لها

(1) أحمد بن أحمد البرثي(زروق):قواعد التصوف، ضبطه وعلق مليه: محمود

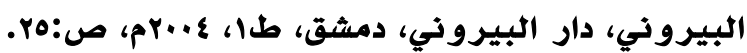

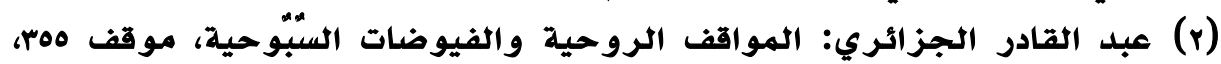
جr، اعتنى به وقلم لله: عاصم إبراهيم الكيالي، منشورات محمدل ملي بيضون، ودار

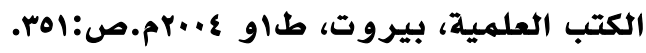

حولية كلية الآداب - جامعة بني سويف


صح أن يكون على صورته، ولها قبل التخلق بالأسماء، وقد صـح التخلق

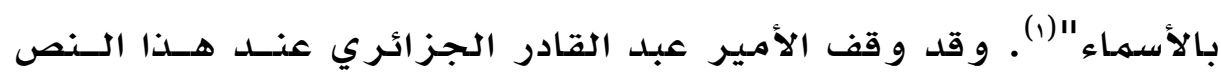
القر آني، ورأى أن كتاب كل إنسان نفسه، فلا يخف الإنسان إلا نفسه، فإنه مـا سبق العلهم؛ إلا بهـا هو عليه من الصـورة التسي ظهـر عليهـا (r) و في ذلك يقول :"والحق -تعالى-إنها يعطي الوجود للمستعد الطاسب للوجود باستعداده، فهو الجواد الحكيم لا يمنع مستعدا طالبًا، و لا يعطي

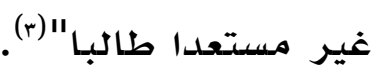
و هكذا فإن الفعل الصووفي في التصــوف العملــي الر اشــــ يعنـي بدعم معر كة الإنسان ضد القوى التي تعهـل علـى تغييبـه بالخر افـة و الجهل، و استلابه بالتطرف و العنف؛ لإسكات إبداعه و تفــرده وتهيـزه و ذاتيته، ضد القوى التـي تعهـل علـى تشـيئئه، و امتلاكسـه، و تغريبـه،

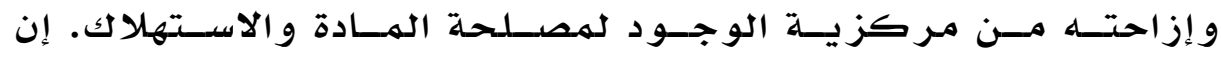
التصوف العملي يحقق إنسانية الإنسان ويصّر على الإيهـان بـه وبأنسه عمد الوجود وبانيه، و أنه القيمـة الكبرى والثروة الحقيقية في الكــون،

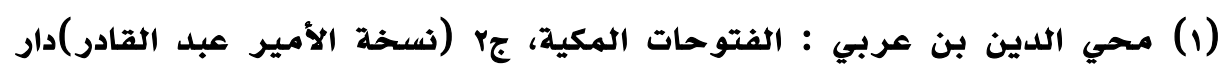

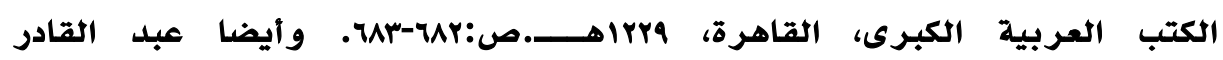

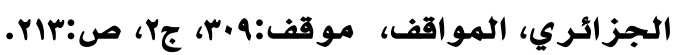

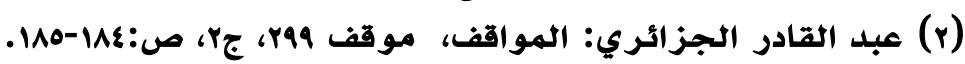

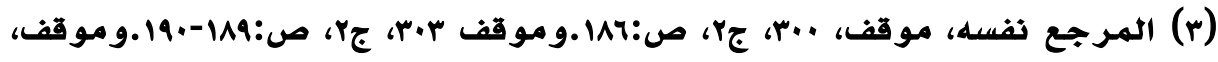

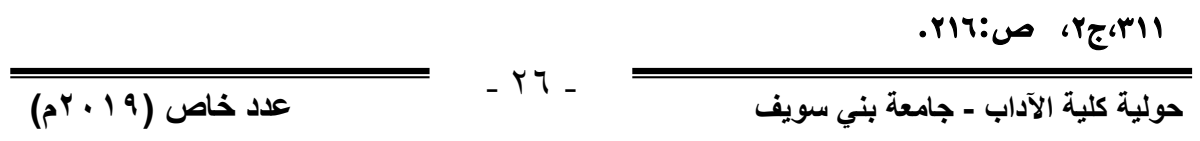




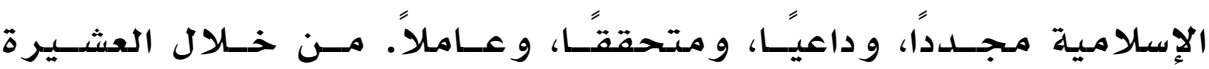
الهـحمدية، و الطريقة الهحمدية الشاذلية، فقد جعل سبيله خلدمة الدين والمجتهمع الإنسـاني مسن بـاب التصـوف، وخدمسة التصـوف بتطهيـره و تحر يره و تجديده و الدفاع عنده (1). و لد الشيخ محمـد زكي إبراهيهم في القاهر بحسي بـو لاق أبـو العلا، و تلقى العلهم ابتداءً على يد والده، ثم التحق بالمدارس الحكومية، و بعدها التحق بالازهر الشريف وحصل على شهادة العالهية، ثـم عمـل

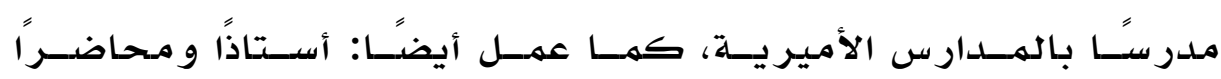
للدراسـات العليا بالمعاهد العالية، و معهد الدراسـات الإســلامية، ومعهـد إعداد الــدعاة، وحاضـر أيضــا بالدراسـات العليــا فـي بعـض الكليــات الأزهر يـة. كما كان أمينًا عامًا لجمعيات الشـبـان المسـلمين و مرشــاً دينيًا، و عمل بعدة مناصب أخرى، و أخيرًا تفرغ غلإدارة جمعية العشـيرة الهحمدية، و نشر فكر تها و دعو تها ومنهجها. و إضافة إلى تلقيّيه علوم الدين و اللغة و التاريخ على يد مشـايخ الأزهر، فقد تعلـم الثـيخ اللغــة الإنجليزيسة، و الفر نسـية، والألمانيسة و ترجم بعض قصائد الشاعر الألماني (هايني رش هايني ) من الألمانية

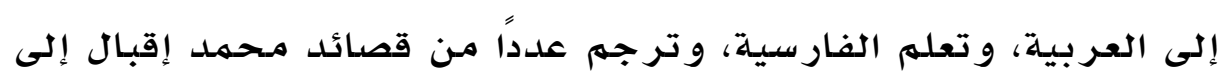

(1) محمد زكي إبراهيم: كلمة الرائد، جr، مطبوعات ورسائل العشيرة

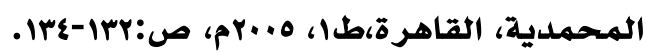
حولية كلية الآداب - جامعة بني سويف 
العربية، والتي نشر بعضها بمجلة (أبو للو)(1). كما اشتغل بالصسحافة، فكتب في الصحف و المجلات السيارة (الأدبيـة، و العامسـة، والإسـلاميـة) منذ أواخر العشرينات؛ فكتب في مجلات: السياسة الأسبوعية، والنهضدة الفكرية، و أبو للو، و الأهرام، و الأزهر، و منبر الإسلام، واللواء الإسلامي، و عقيدتي، والأخبار، وكذلك كتب فـي: لـواء الإســلام، و الخلاصسـة، و العهل، و التصوف الإسلامي، ثم أسس مجلته (المسـلهم ) ســـة .190 م، و قام بوضع منهجها وتحرير ها و إدارتها.

وقد ترك محمد زكي إبراهيهم ثروة علميلة هائلة: نحسو مائــة كتاب ورسالة في العلوم الدينية منها: أبجدية التصوف الإسلامي: عن أهم و أكثر مـا يدور حول التصوف الإسلامي، فيما هـو سـه ومــا هـو عليه، بين أعدائه و أدعيائه. ووكتاب: أصول الوصول: أدلة أهــم معـالم الصوفية الحقة من صريح الكتاب وصحيح السنة. وكتاب: أهل القبلة كلهم موحدون: يبين أن أهل القبلة كلهم موحدون، وكل مساجدهم مســـاجد التوحيــل، لــيس فـيههم كــافر و لا مشــرك، و إن عصدى

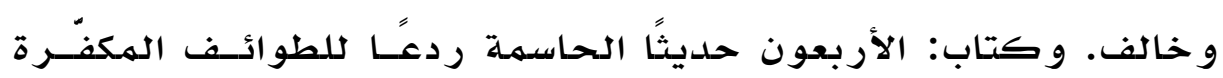
الآثمة. وكتاب :السلفية المعاصرة إلى أين؟ كشف فيـه عـن الــدعوة

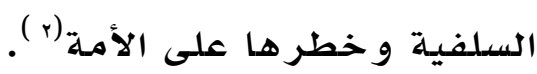

(1) محي الدين حسين الإسنوي: ترجمة موجزة وتعريف بفضيلة الإمام الرائد،

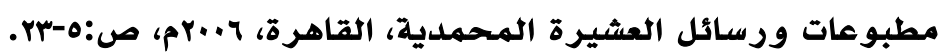

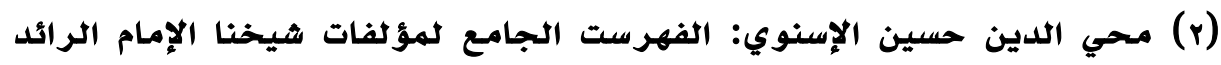

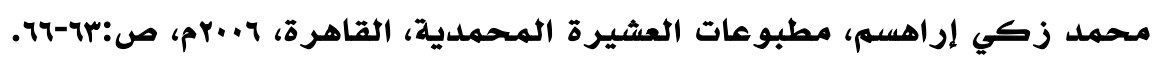

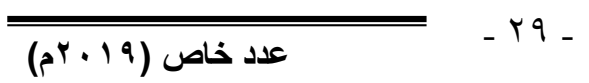


و قد تأثر الإمـام الر ائد بـالمدلرسـة الإصلاحيـة الصدوفية الوطنيـة،

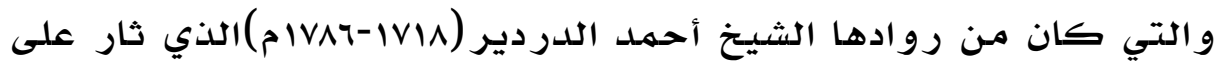
طخيـان الهمـاليـك، وطـالبههم بـالحكم الدسـتوري، و الشـيخ عبــد الله

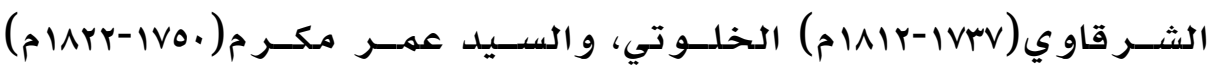
اللذان قادا الثورة في القاهرة على الاحتلال الفر نسـي، والشـيخ حسـن

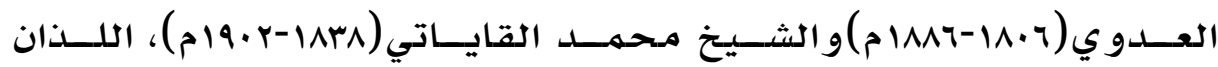
اشتر كا في الثورة العر ابية(1)، كذلك تأثر بهـحمد إقبال، و أسنى على الحرركة الإصلاحية الصدوفية فـي باكسـتان(r ). وق وقـد ثـارك الشـيخ محهد زكي إبر اهيم في الإعداد لحرب أكتوبر الهـيدة سلوام بأعمال التعبئُة و الإعداد و التو عيـة(r)

و كان لكل مـا سبق إضـافة إلى تفاعلــه مــع الواقـع مــن خـلال مشار كته في النهضهة الأدبية، وكذلك معايشته للتطـور ات السياسـيـة و الاجتهماعية للبـلاد العـربية والإسـلاميـة، كل هــذه العوامسل كــان لهـا الدور الواضح في تكوين شخصية الصدـوفي الإصـالاحي مسهــد زكسي إبر اهيهم، والذي يعبـر النص التالي على بناءه العقلي العر فاني، فعنــدما كتب إليـه كاتب، يُعنفنــه بأنــه يـحسبس نفســه فـي قهقـهم التصـوف، و يتقوقع في صدفة التدين الهتأخر، و يعيش متخلفاً في عصور الجمود (1) محمد زكي إبراهيم: كلمة الر ائد، ج|، ص:-1اع-ع|ع.

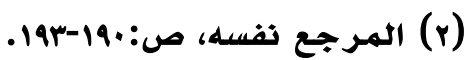
(r) محمد زكي إبراهيه: المنهج، مطبوعات العشيرة المحمدية، القاهرة، طها،

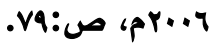

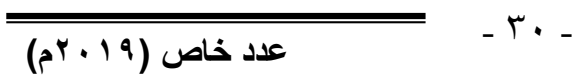
حولية كلية الآداب - جامعة بني سويف 
الماضية، بينهما نحن في عصر تقدمي متحضر ، رد عليسه قائلـا:" إنذـي و أنا رجل معمَمهم مُقفطن لا أزال أثقف نفسي، و أزودها بكل ثقافـة مسن المشرق أو الهغرب، باحثًا عن الحكهــة، جاريّا ور اء الحقيقــة، كلهـا أذنت لي صحتي و أوقاتي وقدرتي، فكما أقرأ تاريخ الإسلام والفلسـفة و تدرج الهذاهب، ونشوء الفرق و النـحسل، و أتـابع الصــوفية والسـلفية، و تطور تـاريخ المسـلمين، و أتـابع أدبـاء العـرب و قصّاصـيه و ناقديسه و مهرّجيه و مفسديه، كذلك أدرس ملامح الفن القوطي و تدرجه إدى الرينسانس، إلى الككلاسيكية القديمة فالجديدة، إلى الرومانتيكية، إلـى التأثر يـة، إلى الواقعية، إلى الرمـزية، إلى الالتز اميــة، إلـى التجربـيديـة، حتى "بيكاسوا "في التصوير، و "أندريه" فـي الأدب، و "استر افنسـكي" في الهوسيقى !!!. و أنا أقر أ لشكسبير، وبوب، وشيلي، وبيكون، وهيجل، و فلامر يون، وجيته، ونيتشـه، إلى سـار تر ، وسومـرست مــوم، وبر تر انســ رسل، و أقر أ كذلك رونسار، و فارلين، ورامبو، و بودلير، و أفرق بـين لوحات جنيسبورو، ورينو لدزر، و أميز فـي مــدارس الموسـيقى بـين صــامويل جونسـون، و بواتـوا، إلـى كـل مــا يتعلـق بفــن المســرح

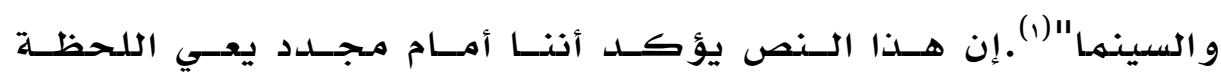
التار يخيــة وهــذه مـن أهــم السـمـات الرئيســة لأصسحاب الخطابــات و المشرو عات التجديدية.

(1) محي الدين الإسنوي: ترجمة موجزة وتعريف بفضيلة الإمام الرائد، ص:ب.rV

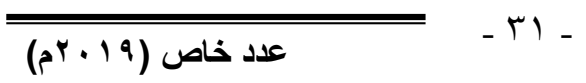
حولية كلية الآداب - جامعة بني سويف 


\section{ثالثًا : تجلديل الخطاب الصوفي:}

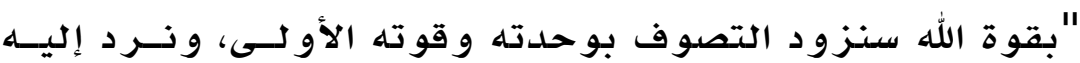

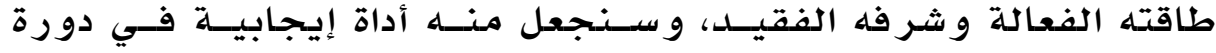
الحيـاة الشخصية و الشعبية و الدو لية، و سنكتل الصدوفيين في الدنيا على ميثاق مـحمدي عملي، ونجمعهم وحدة عالهيـة في أكبر هيئة إسلاهية عر فها التاريخ...إن رسالتنا أضخهم و أكرم مـن أن تكون رسالة محليـة أو شـحسية أو دعـوة انهزاميـة أو انعزاليــة، بـل هـي رســالة حيويـة إيجابية فطرية عالهية ربانية، هي حقيقـة صـوفية ثـر عية، و عقيـدة إصلاحية روحية، فنـحن الهبشـرون بالحسب و السـلام و الــداعون إلـىى الحكمة و النور "(1)

مـ هذا الهـنطلـق أكــد محهــد زكسي إبــراهيم أن الهتصـوف الر اشـل، هو الههموم بواقع أمتـه وو طنـه، والهــدرك لهعر كـة الوجـود الحضساري و النهضــوي في جبهتيهـا: جبهـة تحريـر الأرض، وجبهـة تحرير الإنسان. ووكلتا الجبهتين تحتـاج إلـى الفعـل أولَّ(r). وهكــا انطلق تجديد الخطاب الصوفي عند محمد زكي إبر اهيهم مـن التأكيد على الفعل في الواقع وتحويل التصوف إلـى برنــامج عهـل إصــلاحي، فالصوفي ابن زمنـه؛ يعيش الظـرف الحـاضــر ومشـكلات الــر اهن مــن الأحداث يقول :"التصوف الــواعي الهسـتنير هـو الــذي يشـتر ك مـع

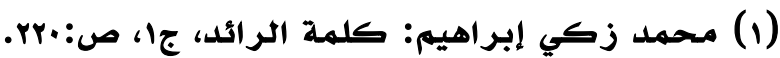

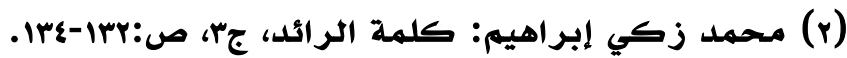

حولية كلية الآداب - جامعة بني سويف


الجماعة الإسلامية في حياتها الخاصـة و العامسة، هـو الـذي يشـاركها

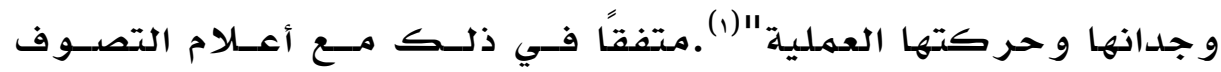
العملي مثل أبي حامد الغزالي، وعبد القادر الجزائري(؟). و تأسيسًا على ذلك ذهب الشيخ الر ائد إلـى أن الواقـع الحــالي يتطلب ضرورة تجاوز التصوف الجدلي القائم على الفلسفة مـما ينسب

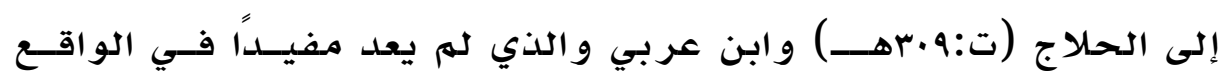
الصو في، و أن يكون وجوده مححدود بمقــار العلـهم الخـاص والتــاريخ، ور أى أن هذا اللون من التصوف انتهى برجاسـه. ورغـهم أنسه يـرى أن الموقف منه هو: حسن الظن بهم، وتأويل كاملهم على محمل مقبول، خاصة و أنهم التزموا الرمز و الإشـارة و عمق العبارة، أو أذه دُس عليهم، إنّا أنه يرى أن مرحلة جديدة قد بدأت ويجب أن يكون الاهتمــام فيهـا بما ينفـع الأمهة، و بهما يحيط بها من أهوال و أحداث، من لـهم يهـتم بهـا

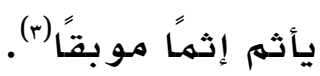
و لعل من أهم الأسس التي تنبــه إليهـا محهـــ زكـي إبـر اهيم لتفعيل مشرو عه الصوفي هو: تجديد عرض الخطاب الصو في وتبيانسه

(1) محمد زكي إبراهيم: المرجع السابق، ص:9 (1)

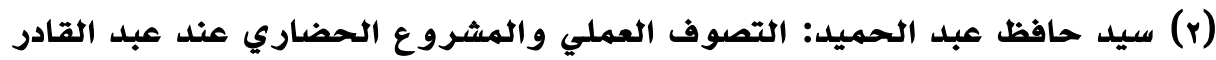

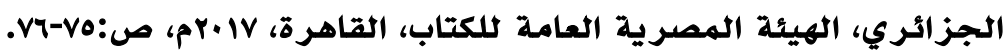

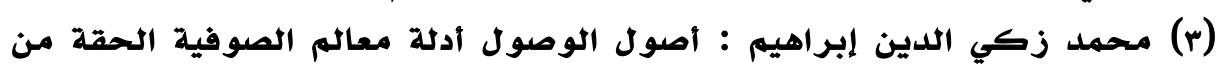

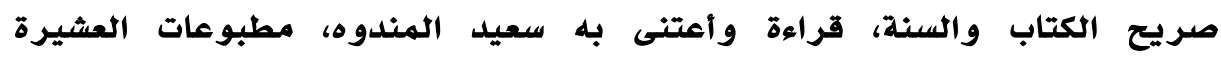

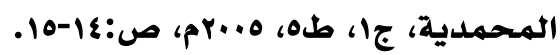

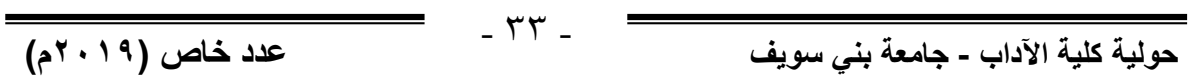


بمها يـلائم العصر ، يقــول: "نحسـن الآن مُطـالبون بعـرض هــذا العلـهم الشريف الهؤصل عر ضسا علميًا، لا يتعارض مـع معقول و لا منقول، و لا ظاهر و لا باطن، ويعطي كل ذي حق حقه"'(1). وقد فعل ذلك الإمسام

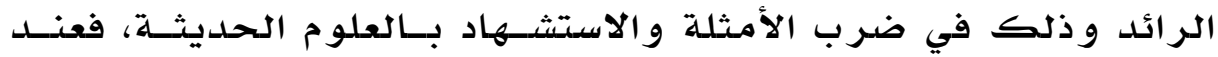
حديثه عن الكر امـة و تحليله لفكرة (الهمدد، و النظـرة ) عنــد الصــوفية يقول:" وقد اتفق العلهم الحديث و القديهم على أن ذظرات الناس تختلف باختلاف الانفعالات، وباختلاف شحنتها مـن القوى والطاقـات البـاطنيـة في الإنسـان، و هذا أمـر محسسوس فلكل نظرة معنى، و لكل نظرة تأو يـل، و لكسل نظــرة حسـيث روحسي تفهمسـه العقـول وتتـأثر بــه القلـوب و العواطف.... وهكذا يختلف معنى النظرة في القر آن الهجيد باختلاف

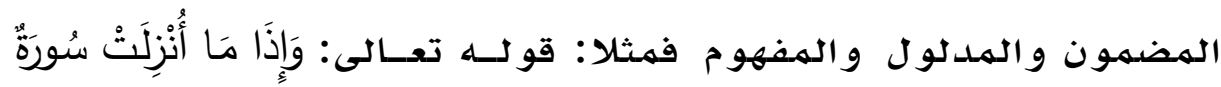

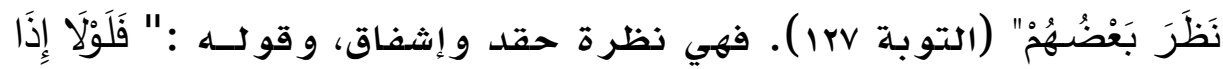

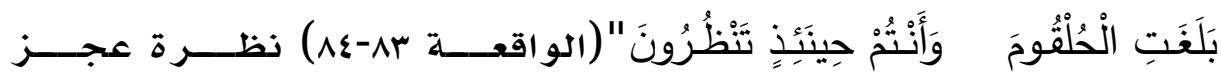
و إشفاق...فالنظرة إذن نوع مـن الإمداد الغيبي تُرْل بـه عين البصر أو البصيرة، و في إشعاعاتها سـيالات قوية و تيـارات نفــاذة مُؤثرة، و أنـت و اجد تجرب ذلك مكررة في اختلاف نظراتك اليوميــة إلـى أو لادك ومـرؤوسيك، والناس كلههم مهـن تتعامل أو لا تتعاهل معهمم في حالتي الر ضـا و الانقبــاض... ألا تـرى نظــر ات قــواد الجـيـوش والحرركـات

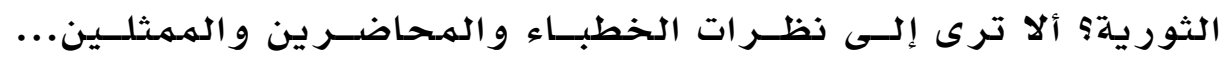

(1)محمد زكي إبراهيه: المرجع نفسه، ص:19r. حولية كلية الآداب - جامعة بني سويف 
وكل ذلك دائر في المـجال الإمكاني المحكوم شرعًا بالإباحة، وهو لا يتعارض مـع العل، و لا مـع النـاموس الكوني، ولا مـع معقو ليــة الأثــياء، و لا مــع معلـوم بالضـرورة مسن ديـن الله، ولا مــع تجسـارب العلسم

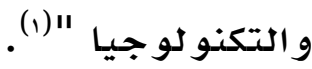

كما أكد الإمهـام الر ائسد علـى أنسه لا تعـارض بـين الشـر يعة و الحقيقة، مؤكداً أنه لا يمكن تجديد الخطاب الصووفي إلا بنـاء علـى هذه القاعدة، وانتقد مس يفصـل بـين الشــريعـة والحقيقــة: ويـرى أن الشريعة شيء والحقيقة شيء آخر ، و أن العبد لا يزال ملتزمسا حسدود الدين حتى ينتقل من مقام الشريعة إلى مقام الحقيقة فتسـقط عنسه التكاليف، ونرى ذلك في قو له تعالى: " و أعبــد ربـك حتـى يأتيـك اليقين"(الحجر ه9). و قد قالوا بأن اليقين هو مقام الحقيقة فإذا وصل إليه الإنسان سقط عنه التكليف والحدود و فهـل كهـا فعسل الخضـر . و أكد الشيخ الر ائد على أن القول بمـخالفة الشر يعة للحقيقـة زندقـة ربما تفضي بصاحبها إلى الردة بعد الإسلام، و أوضح أن اعتر اف الإسلام بالشريعة على أنها ظواهر الأمور وصور العبادات والحقيقة على أنهـا روح الأمور وحكمة العبادات ليس معناه أنهما منفصمين بل لا يمكن أن يقوم أحدهما بلدون الآخر كالروح في الجسد، والحسرارة فـي النــار، و الحلاوة في السكر ، فالتفرقة بينهما مستحيلة عقلًا ونقلًا وو اقعَّا، ور أى أن القول بذلك هو دسيسة على التصوف الإسلامي موضـحًا مــا

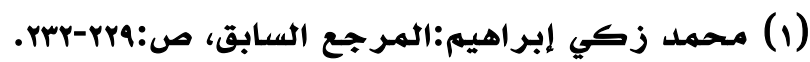

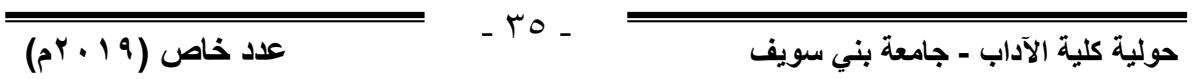


يتمسك به قائلًا: " نحن نسلهم بـالغيوب و الأسـرار و الحكسـمَم ونسـلهم بالإلهام و الكشف و الكر امـة، و لكـن علـى أسـاس العزيهــة فـي الــدين و الاعتصام بالسنـة، والاحتياط الهطلق في العبـادة والأدب، وهذا وحسده هو باب الولاية و معراج القطبانية(1). و لهما كان لكل خطاب معوقات تهدد تحققه، و تهدف إلى تشويـ و تجميده، رأى زكي إبر اهيم أنه لا يمكـن تجديسـ و إصـلاح الخطــاب الصوفي دون الكفاح في جبهتين: جبهة المتهصسوفة أدعيـاء التصـوف، الذين أفسدوه وشوهوا صـور ته، وجبهــة الهتهســلفة أعسـاء التصــوف و التسامح، و أو لياء العنف و التطرف، و أوضح أن كلا الفريقين يجهـل حقيقة الدين وحقيقة التصوف، و أنهما يعطيان الفرصة لخصوم الأمسـة في استهلاكها ذاتيًا واحتر اقها داخليًا بإثارة العداوة و البغضاء حول مـا فيه قو لان أو احتمالان، و ما لا علاقة له بصميم دين الله (؟). فإن قد عجبنا من فلول تمصدوفت فأعجب منهم عصبـة قد تمسـلفو و في هـدم أركسان ملادئل تغالى أو لاء و هؤلاء ض

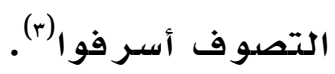

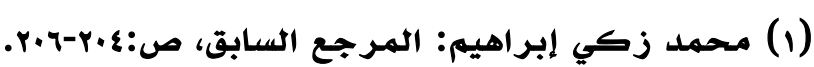

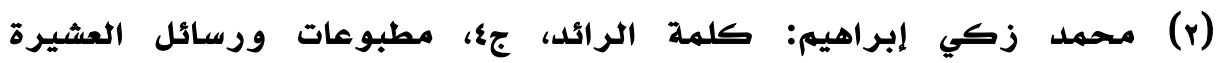

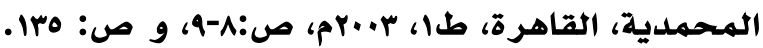

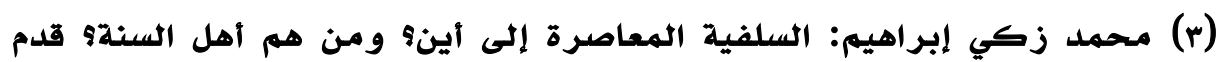

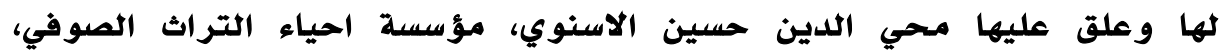

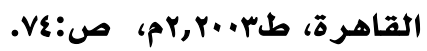

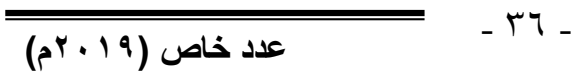


وقد انبرى الإمـام الر ائد لتفنيد خطاب التمسلف وتحليله نفسياً و دينيًا و فكريًا و اجتهاعيًا، فأكد أن السلفيـة مـا هـي إلا دعـوة سياسـية تخدم اتجاهاً دو ليًا معينًا هو الذي ابتكر ها و أيدها و مكسّن لهــا؛ لتكـون رأس الحربة في العرووبة والإسـلام بـاسم العروبـة والإسـلامج، ورأى أن التمكين لهذا المـذهب مـا هو إلا عقوق للوطنيـة، سواء مـن قبـل السـاسـة أو رجال الدين الذين احتر فوه طريقًا إلى الثراء و الشهرة، غير عابئين إن كانوا خـانوا الدين أو خانوا الـوطن، أو أصـبـحوا- بعلـهم أو جهـلعمهلاء لدول خارجية يستعهلونهم في إثخال الأمهة عن مشكلات و اقعهـا

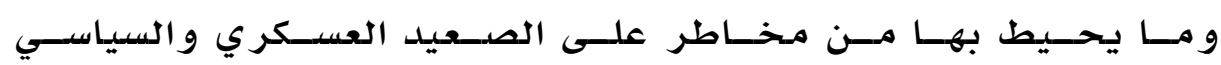

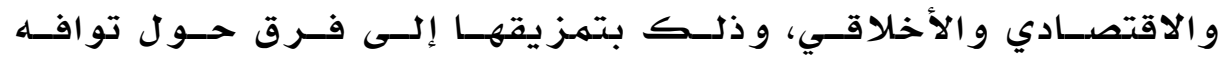
الفرووعيات الاجتهادية، أو السنـن الاعتيادية(1). ور أى أن مـن أخطر فـتن هذا الاتجــاه فتتــة مسنـح الــولاء لغيـر الـوطن بـاسـهم الـدين والســـة

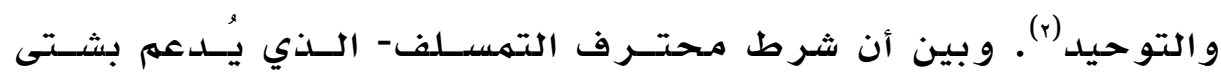
الامتيـازات، مـن مـال وصحف وقنوات إذاعيـة، ووكافـة و ســائل الدعايـة و النشر - ألّا يحفظ لمسلم حرمـة، و ألا يتر فع عن الانغماس في مقـاذر السبـاب، و أن يستتقص الرسـول و مشــاهير الأمسـة، و أن يرمــي السـلف

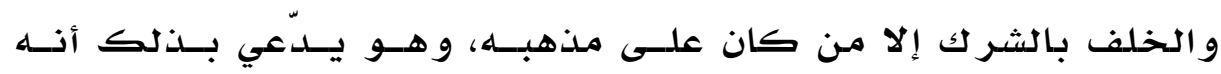
يحافظ على دين الله كتابًا وسنةة، فها يزال أحدهم يقول ما لا يعتقد

(1) محمد زكي إبراهيه: كلمة الر ائد، جr، ص:•rع- اسء.

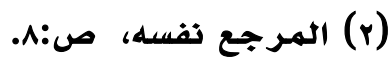

حولية كلية الآداب - جامعة بني سويف


حتى يعتقد ما يقول، فليس مــنهم مسن مــؤمن بدعوتـهـ إلا هـو علـى الحقيقة مدخول الإيمان بغرض أو غفلة، أو جهالة(1).

وكشـف عـن أن كثيـرًا مــن النــاس يعتنقــون هــذه الــدعوة

بمسيمياتها المختلفة من و هابية أو سلفية بحسن الظن أو بحب التعبسد بالتزام التزمت والتجمهد، أو بالتعقيد النفسي الــذاتي الــذي يجــد فـي مخالفة الجمهور ما ير ضيه و يريحه، و يعوضه شعوريًا عما افتقده في ذات نفسه أو شئون حياته، و أن منههم من يعتنـق هـــا الهـــــب تقليــاً و مخخالفةً و تعصبًا وضيق أفق وكفاءة(r).

ور أى أن من أخبث ألوان التفكير الذي أعتنقه دعاة هذا المدهب هو منـحهم أنفسـهم سـلطة الكهنـوت فـي الإسـلام ومسن ثـم الحكــم

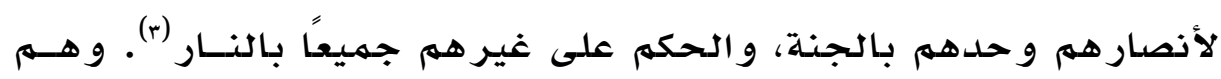
بذلك بعيدون عن الحياة و تطور ها يكرسون للتقليد و الجمـود و كـل همهمه ألّا يحاول أحد مشاركاتههم الوصـاية علـى ديـن الله، ومفـاتيح

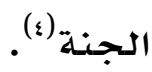

ولاكــــوا دعْوى السَّلفية

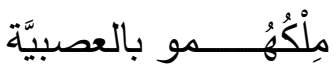

خصّوا أنفُسهم بالتَّوحيـد فالسُّنُّة إرثُهُهُوا والجنَّة

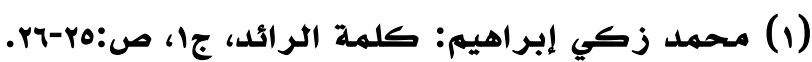

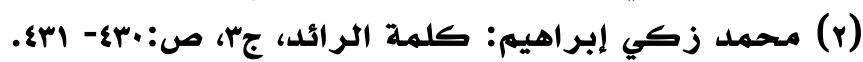

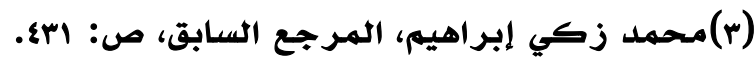

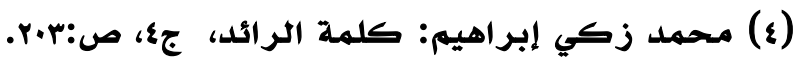

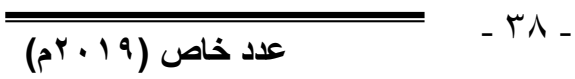
حولية كلية الآداب - جامعة بني سويف 


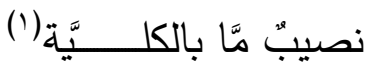
أو ليْسَ لغيركمو في الـدَّين ذا ابتداع، وأنهم سُنيـــَّة فرَّقونا وكفَّرونا وقالـــوا يدرك السـر أو يرى الخلفية ضللوا سُذَّج الثباب ومن لا في البلاد الدماء والوحشية (؟). هاهمو روَّعوا العباد وأجرَوا و برغم تأكيده على خطر هــذه الــدعوة إلا أنسه ذهـب إلـى أن مستقبل التهسلف إلى زوال، و أن مثل هذه الطائفة لا تحسـد على خيـر مؤقت تجده اليوم، فهو منكوس غداً و معكوس، ما دام في هذه الأمهة من يحمل المشعل و ينبه إلى الخبايا، ويرفع الأستار عن الأشرار، فلا بارك

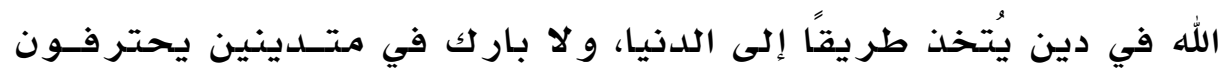

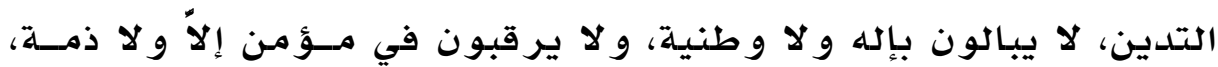
وسحقًا لحرفة تتلف الذمهم، وتفسد اللسان و تطعن الدين و الوطن" (؟). و على الجبهة الثانية ذهب زكي إبر اهيهم إلى مكافحة تصـوف الاســرزاق و الــدجل و أصدحابه الـذين يمثلــون الجهلـوت و الرجعيــة

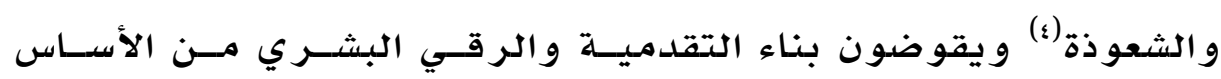
والتوزيع والنمد زكي إبراهيم: ديوان البقايا، الجزء الثاني، الوابل الصيب للإنتاج

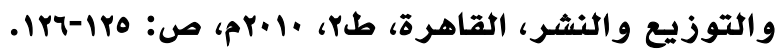

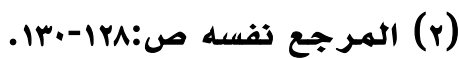

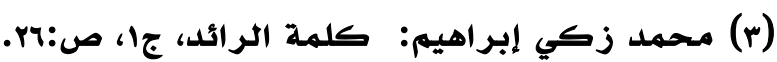

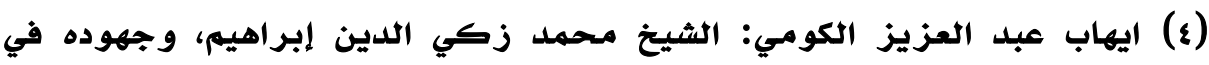

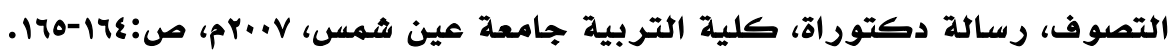

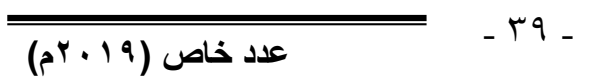


وخاصدة في مصر مستقر الزعامـة الإسلاميـة، وهم جماعة المتهصدوفة

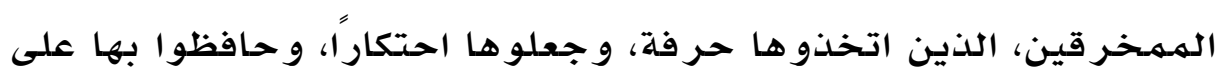
كل دنية وكل خر افة، و من هنا كانت خطورة هذه الطائفة، مؤكسـاً أن التصوف الشرعي بريء مــن هــؤلاء وومـا يعملونسه ومــا يقولونــه، و الإسـلام ورسول الله و أولياء الله بر اء منهم (1). وقد لفت زكي إبر اهيهم انتباهنـا إلى أن الاحتلال قد اسـتطاع

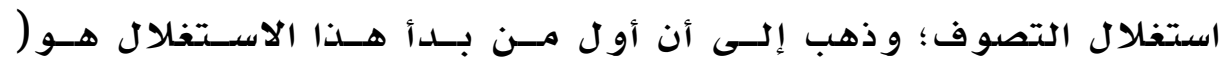
نابليون بونابرت) في عهد خليل البكري(ت:4.1ام)، واسـتطاع مسـخه و تشويهه، و تحويله إلى أداة تجهيل، وتضـليل، و تحريسف، و تخريسف ، و استغللال، و استعمهار (r) وقد أدى ذلك في رأيه إلـى تــهور القـيهم والآداب الصــوفية، حتى أصبـحت الهشـيخة وظيفــة "ميـري" تُنـال بـأرخص الأسـاليب، و أحطها، و أنذلها، و أصبـح لعـق نعـال الحكــام، وتمريــخ الخــدود علـى عتبـاتهم، هــو العبــادة التـي يفخــر بهـا الثـيوخ، ويتتنافسـون عليهـا، و تدهورت تبعًا لذلك كل المعاني العالية في التصوف، فإذا هـو و بـاء

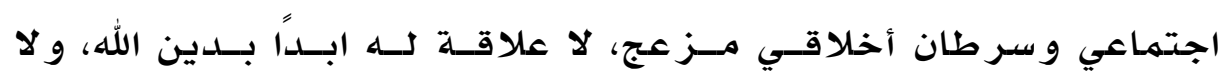

(1) محمد زكي إبراهيه: كلمة الرائد، جا، ص: شبr.

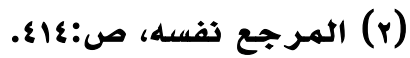

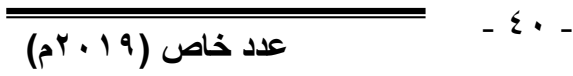
حولية كلية الآداب - جامعة بني سويف 
بتصــوف الهســلهين، و أصسبـح مسن الهتعـين جهـاده حتـى يسـتقيهم أو

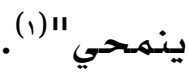

و من ثم فقد نادى بتطهير التصوف مـن صوفيـة الخر افــة التــي

تربت على خدمـة الاستعمهار وقال: " لقد آن الأوان لتطهيـر التصــوف في مصر بكل ألوانه و أسـهائه و أو ضـاعه، و نحـن لا نر يــد أن نسـتحدث لهؤلاء قانوناً للتطهير، و لكنـنا سنأخذهمر بهقررات أنمهة التصسـوف فـي مؤلفاتهم، و نطبق عليههم مـواد القوانين التي و ضعها شيوخهم و أنمــههم و أجدادهم للمشيخة قبل قرون وقرون، مستمدة مـن كتـاب الله و ســنة رسو له صلى الله عليه وسلهم فهـن صدقت عليه هذه القواعد بقـى، و إلّــا فليذهب غير مأسوف عليه، سيداً كان أو مسبودا، و صاحب سجادة كان أو صاحب حصير "(r)"

ليس التصوف رقص الر اقصين و لا

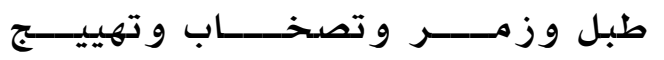

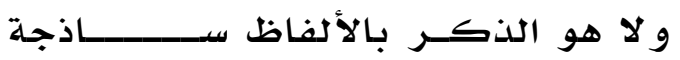

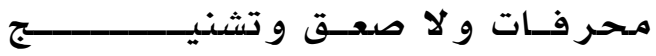

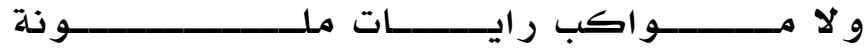
فيهــــا لهـــــا يغضب الديان تروويج

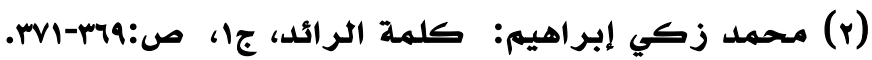
حولية كلية الآداب - جامعة بني سويف 


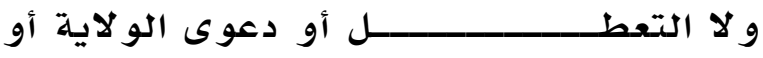

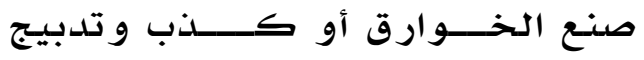

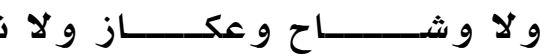

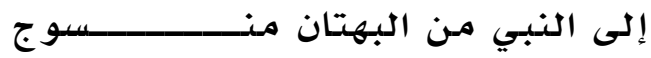

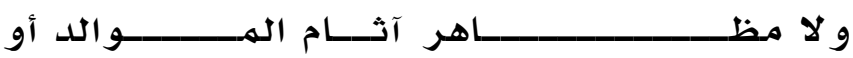

تكاث

مؤكدا أن :" التصدوف وهو مـا جاء بـه الوحي من علـهم و إيهــان

و عمل وخلق وجهاد و استعاءلاء، هـو ضــرورة حتمـيـة لتحقيـق النجــاح العسكري و الاقتصادي و الاجتهـاعي و السيـاسي و العهـر اني و غيرهـ. فهدف التصوف إصدلاح الفرد وبإصـلاح الفـرد يصـلـح الهمتهــع، لأن الفـرد الصالح لا يصدر عنه إلا العهل الصـالح، والأثر الصسالح"(؟).

\section{رابعًا : طبيعة اثمل الصوفي:}

يرى مهحمد زكي إبر اهيهم أن خصيصدة التصدوف الهميزة له، هي أنه فعل إصدلاحي إيجـابي روحي أصيل، ووهو نهايلة الشـوط، يبــدأ مــن الأعماق، و يهذب الخصـائص التي ينبني عليها الإصـالاح الحيـوي العـام، و يؤهل الفرد و الجمهاعة للتقدميـة المسـتقرة علـى أســاس معامـــة الله

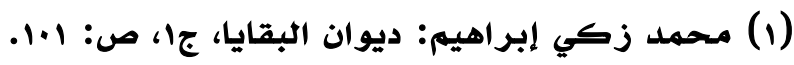

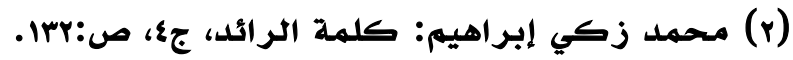
حولية كلية الآداب - جامعة بني سويف 
و الود معه، و الاستفاضدة منه و التعلق به، و يتساءل شيخنا الرئد:إن كان الصوفي المبتدئ يتحرى معالي الأمور، ويضع خلاف الأو لى في رتبـة الحرام، حتى لا يدع ما لابأس به خيفة مهما بـه بأس، فهـو خيـر كالـه ونور كلله، لا يجتهـع معه شر و لا ظلام، فكيف إذن بالصوفي المنتهـي بعدى" (1) (1)

فأساس التصوف العملي عنده هو فعل وتجربة تصل بـك إلـى التذوق و الصفاء و الهشاهدة و الوصول إلى سر الذات(؟) و الخلافة علـى الأرض، وسبيله العلهم و العبادة، فلا يغني عنك فيه سواك، فإنه لا يمكن أن يتذوق لك منـه غيرك، كما لا يمكن أن ترى بعين رجل آخر (r)؛ أي أذه يبدأ كتجربة فردية تنطلق من فعل الذات.

و الفعل الصوفي لله مححددات أهمها المعاناة و التــذوق، و لــذلك

فهو يختلف عنده عن الفعل الفلسفي العقلي، فالفعل العقلي قائم علـى التصور و التخيل، بينهما الفعل الصووفي قائم علـى الإحســاس والتعهـق، والمعاناة والتذوق، العلهم والفلسفة فعل عقلي، بينها التجربة الصوفية فعل قلبي، فالهنـحَح الروحية، و الإثر اقات القلبيسة، هـي نتيجسـة الجهـود و الأعمال، والصوفية ليسوا أصحاب أقوال، و إنما أرباب أحوال و أفعـال،

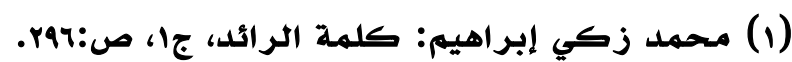

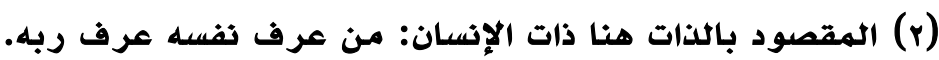

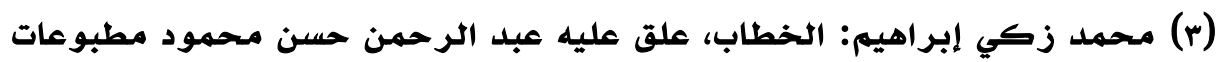

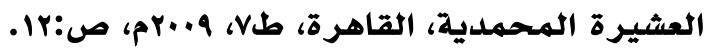
حولية كلية الآداب - جامعة بني سويف 
و لهم ينل المشاهدة من تر ك المجاهدة، فهن لهم يسع لهم يصل، ومن لـم يلتمس المعارج لا يتسامى و لا يرتقي، و من له يتحر كك له ينتقل (1). و يجعل زكي الدين إبر اهيهم الفعل الصو في أعلى مـر اتب الفعـل من حيث العلاقة بالله، ويتضـح ذلك من خـلال تمييـزه بــين الفقيـه، و العابد، و الزاهد، و الصو في يقول: " الصوفي أكثر من فقيه، فالفقيه و قف عند الأقوال، والصوفي أكثر من عابد فالعابد وقف عند الأعمال، أما هو فقد جمـع بينهما، فأثمـر الأحوال، والصوفي أكثر من زاهــد إذ

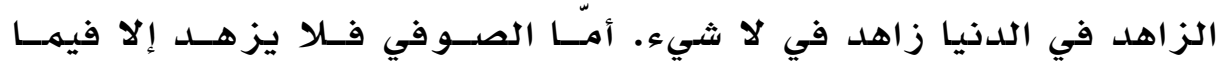
يحجبه عن الله، و بهذا يجعل الدنيا في يده، لا في قلبه" (؟). لذلك نجده يُعـرف التصــوف بأنسه علـم فقـه المعرفــة فهـو تصحيح الإسلام، و تحقيق الإيمان، وتأكيد الإحسـان، والتصوف التقوى،

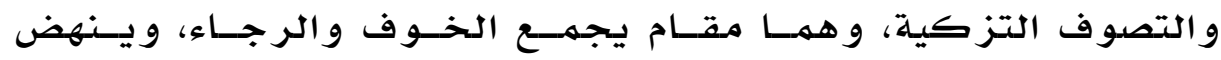
بالعقيدة و الخلق، وبه تتحقق إنسانية الإنسان، من خـلال الجمــع بـين الدنيا والآخرة التي يرى الإمام الر ائد أنه مـا مـن آيسـة فـي القـر آن إلا و هي تربط بينهما وتجعل الــدنيا وسـيلة للآخـرة مسـن بـاب التقـوىى وطريق التزكية) وفئ.

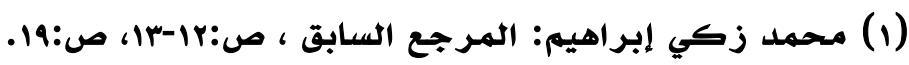

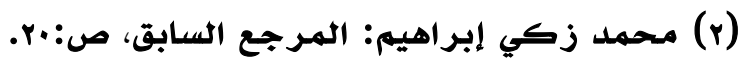

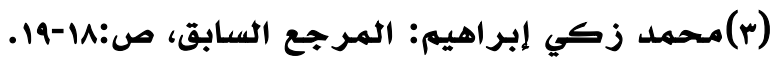

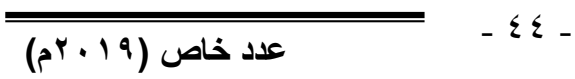
حولية كلية الآداب - جامعة بني سويف 
وبذلك فالفعل الصو في يبدأ من الداخل مــن أجسل أن يســافر الصوفي إلى باطنه ويدرك سر هويته (من عرف نفسه) ويعرف ماهية و ظيفته فيما بينه وبين الخالق (عبودية و إنابة، و تطهرًا و تبتلًا، و تودًّا إلى العاله الأعلى، و هذه هي الوظيفة الأسساسية له التسي تنستج بطبعهـا آثار الإنسانية الكاملة فيما بين العبد والعبد. ووظيفته فيما بينه و بين الخلق (إيمانًا و عملًا، و استخلافًا في الأرض و استعمارًا فيها، و تسـخيرًا

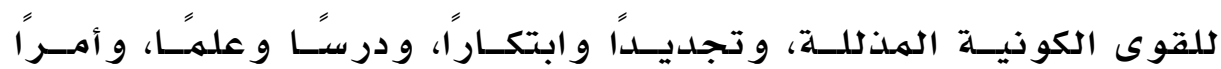

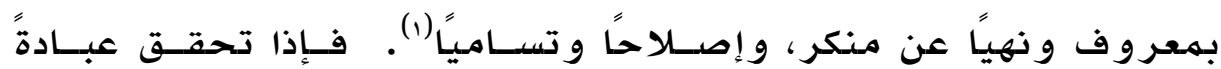
وخلقًا و عملاً كان ربانيًا (كونوا ربانيين بها كنتهم تعلهـون الكتــاب و بما كنتهم تدرسون) آل عمر ان(va)(r) و (r) و من ثم فالصووفي لا يكـون ربـانيّا إِّا إذا أدى وظيفتـهـ نحـو الخالق والخلق حتى تظهر آثار الفعل الصوفي فـي الواقــ، فالإنســان الرباني هو من يتحرى بربانيته معالي الأمور، فلا يأوي إلى منقصسـة، و لا يقع على تافه، و لا يلتفت إلى صغيرة، ولا يتبر م بنازلة، و لا يتعلق بشبهة، و لا يقبل الدنيّة في دينه، و لا يقف في آخر الصـف مسن دنيـاه، و لا يقنع مـن المعالي بما أدرك، و لا يلتقط فتات موائد غيره من علــم أو فن أو تجديد أو ابتكار، و لا يجزي حسنة بسيئة، و لا يذهب بنفسـه حتى يكتب في الجبارين. ووهكذا يهيهن على قوى الكـون فتنفعسل كـه،

(1) محمد زكي إبراهيم: كلمة الرائد، ج1، ص:79.

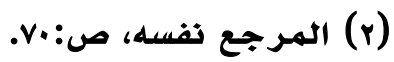

حولية كلية الآداب - جامعة بني سويف


فيكشف أسر ارها، و يطو عها لخير الإنسانية، فالر باني بقلبه و باطنه مــع الله، مخبت منيب، وبظاهره في خدمة الحياة منتج مـجسل، إيجـابي فـي حدود طاقته، و في مدلى وظيفته وحرفتــه، عقليسـة أو عمليــة، فيـؤدي بذلك حق العبودية في الباطن، وخدمـة الإنسانية في الظاهر، فهذا هو الإنسان الذي نؤمن بـه ونبحث عنه (1). و بذلك فالفعل الصو في يصلح ما بالنفوس بادئًا، حتى يتهيأ له إصدلاح مـا بالأكوان على أساس إصـالاح النفـوس، ورده إلـى الحقيقـة العلية في إنسـانيته واسـتغلال روحانيتــه فـي بنــاء النهضــة، و القيـام بحركة الإصدالاح والتطهر ؛ أي إدمـاج التسـامي الروحسي فـي الحيـاة

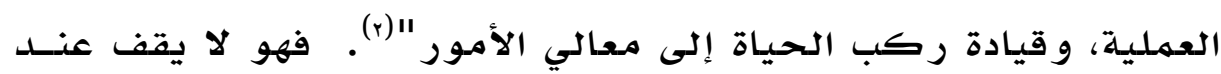
حد إصدلاح الفرد، بل يتجاوزه إلى الأسرة ثم المجتهمع ثـم الإنسـانية، فالفعل الصو في فعل منفتح لا يقف عنــد حسد معسين و هــذه خصيصسـة أصيلة في طبيعته.

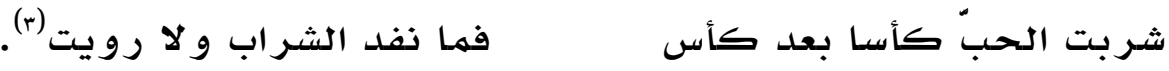
والر جل الرباني إنسـان مترفــع متســام إيجــابي مــؤثر، إن لــم يصدر عنـه الخير، لن يصدر عنـه الشر، لذلك كــان التصـوف فرضـا

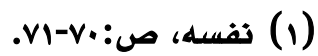

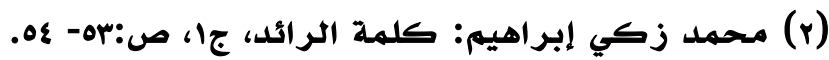

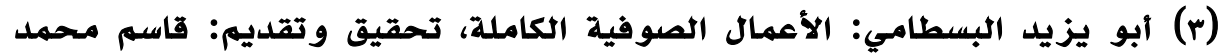

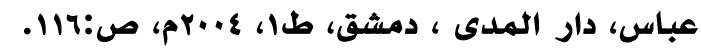

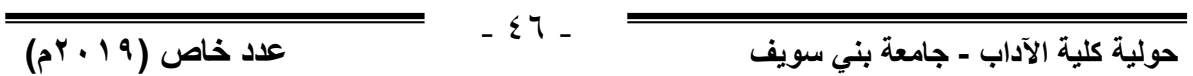


عينيًا لأنه أمثل الطرق إلى إيجاد الهـجتهــع الفاضـل و الفـرد الكامـل، و الدو للة الهـاجدة(1)

و يتميز الفعل الصدوفي بأنه وهو في مقام التخليـة، ووفـي مقــام التحلية، في مقام بناء النفس، والأسـرة، و الدو للة، وفي مقام بناء العالم لا ينطلق مـن مـجرد الواجب الكانطي، أو الواقـع البـراجهــاتي، بـل مــن الحب، فالحب أصل كل فعل صوفي :

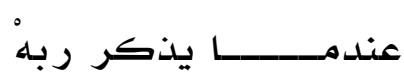

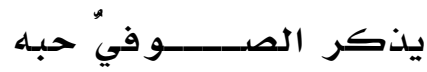

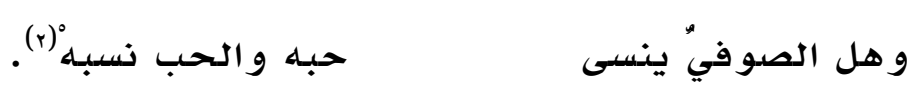

وحبـه ليس فقط حال وجداني لا يتجاوز شعور الصوفي و إنها

هو حال يستحيل إلى فعل يتجلى، ويتمظهر في الواقع المعسيش أمسلا

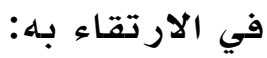

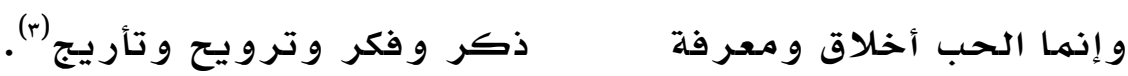
و لذلك نرى الإمـام الر ائد يقول: "وتصور -يـا و لـدي- مجتمعـا

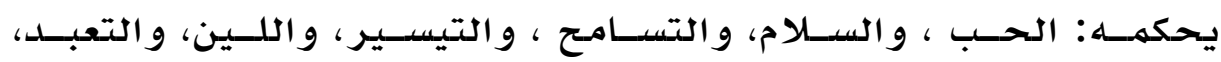

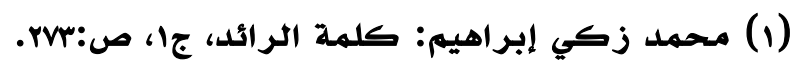

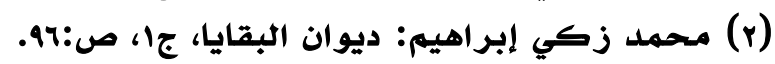

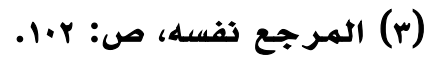


و التعاطف، و الشرف، و الإيثار، و تحسـري معسالي الأمـور، كيـف يكـون أفر اده؟ و كيف تمضى حضار ته؟"(1).

وهنـا نستطيع أن نقول أن فلسفة الفعل الصـو في عنــده تنتقــل

بالفعل الصوفي من كونه فعل ذاتي إلى الفعل الحضـاري الذي يؤكســ على قيمهة الإنسان وتحرره من كل شيء يستعبده غير الله، هـو كهـا يقول: "رد اعتبـار الإنسـانية للإنسـان، بعد مـا فقـــ اعتبــاره واسـتعبدته المـادة، ومكاره الأخـلاق، و الكيـوف الهتحكهــة، و الثـهوات الهظلهــة ،

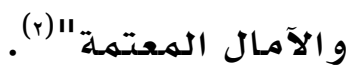

و هو بتأكيده على فعل الحب و ما يتبعـه مسن تعـاطف وتســامـح و لين إنها يؤكد على أن الفعل الصوفي فعل إيجابي فهـو دعـوة إدىى القــوة و العلــهم، و العــزة، و العـدالــة، و المســـاو اة، والإحيــاء، و التكافـل، و التكامل، و التجديد، و الابتكار، و السيادة، والقيادة، لأن الله خلق الهسلهم الحق ليمارس كل هذا(؟). وهو ينفي بذلك الأفعال السـالبة فـالعنف، و القهر، و القسـوة، والتعسالي، و الخبـث، و التغــالي، و البــذاءة، و التعـالهم، و الاندفاع، و أذى الناس أقذار لا يعر فها التصوف. الذي أساس الفعل فيه الحب والحنو على كل المخلوقات، يقول الشاعر الصوفي:

(1) محمد زكي إبراهيم: الخطاب، ص:rv.

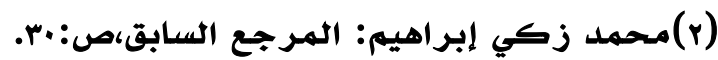

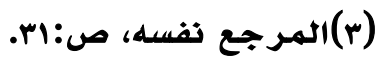




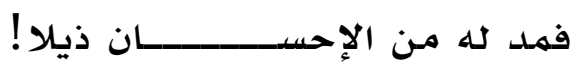

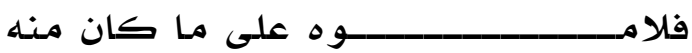

وقالوا: كهم أنلت الكلب نيــــــالح؟

فقال: دعـــــــــوا الهـلامـة إن عيني

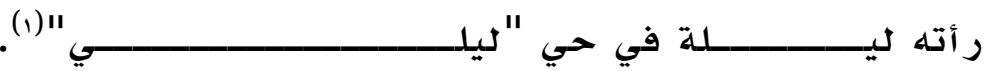

\section{خامسًا : تجليـات الثمل الصوفي في الهواقع:}

من خلال مفهوم التصوف العملي(الهستنير) عند زكـي الــدين إبر اهيم الذي هو: "إيمان و عقيدة، و علهم و عمل، و أدب و محبـة، و عبـادة ور ياضدة و تربية ودعوة وريادة، وسلو ك تطبيقي إلـى رحساب الأسـر ار و الأنوار، فهو طلب الكمال، وطلب الكمــال فريضــة علسى كـل مسـلم

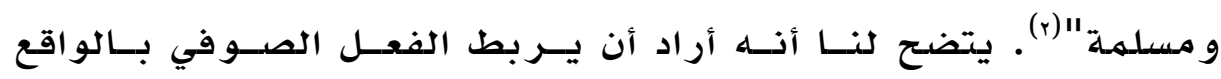
المعيث بكل أبعاده السياسية و الاقتصادية و الفنية والثقافية و الدينيـة،

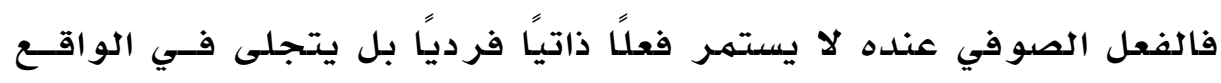
ليحاول حل مشكلاته، و فعل الخضر مـع موسـى كــان فعلَّا اجتمـاعيًا، ذهب الخضر بهموسى إلى الهجتمع و لهم يهرب به إلـى جبـل أو مغــارة،

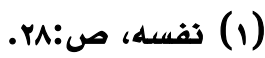

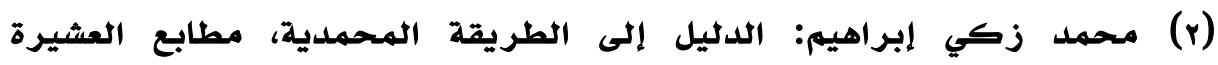

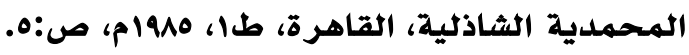

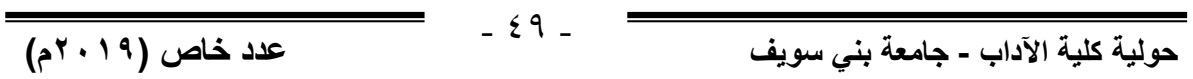


و بذلك يكون العلهم اللدُّي علهم لإصدلاح الواقع ، يقول الإمهـام الرائد: "لما كان الصدوفي يعامل الله في أشخاص خلقـهـ...فهو يحــافظ أبـدا" على ألّا ير اه الله حيث نهاه، و لا يفقده حيث أمـره، فكل مـا يصسـدر عنــه مـن أعمال الدنيا إنها يصسـدر عـن إحســان وإيقـان و احتيـاط و إجـادة مطلقة، مفضيـة إلى كل تجديد و تقدم وابتكار، فكل ذلك عنده عبـادة مهداه إلى الحق...وومن هنا يظهر الأثر الكبير للتصدوف الهستنير فـي دفع عجلة الحياة كلها إلى الحركــة و التسـامي و التقــدم الحضـاري، و هكذا نرى التصدوف الحق إنما هو: دنيا ودين، وعبادة وخلق، وكفـاح

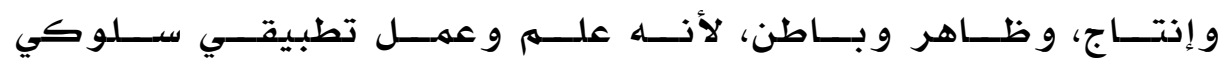
رفيع....ولزو مـه للشاب والهشيب ضرورة حيوية مـادية وروحيـة معًا، فهو الطريق الوحيد لرد الاعتبــار الإنسـاني، فلـيس هـو السـلبيـة و لا (1)" الانطو اء أبدا"

وهكذا يكون الفعل الصدوفي عند زكـي إبـر اهيهم فعـل إيجــابي منتج: "والتصدوف من حيث هو عقيدة وخلق يعتبر من الوجهة العلمية و الاجتهماعية ضرورة حتهية لا بلديل لها في مكافحة الجريهـة، وتقويهم الانحر اف، وإيقاظ الضهير ...إذ الصدوفي يعامـل الله فـي كـل مطامبـ الحيـاة، فهو إذا (أي التصوف) ضرورة أكيدة لخدمـة الحيـاة الدينيـة

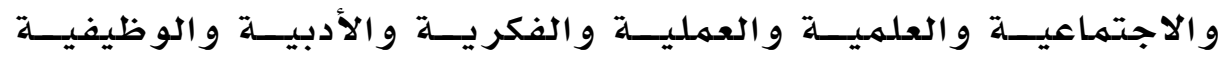
و الجندية والتجارية و التربوية و التقدمية و غير ها؛ أي أنها لازمـة لكل

(1) محمد زكي إبراهيم: كلمة الراتد، جع، ص:وسا-Irr. حولية كلية الآداب - جامعة بني سويف 
إنسـان، يحتر م الإنسـانية، ويقدر خلافة الإنسان في كل موقع وموضـع من خريطة الحياة" (1)

وقد أراد بــلك أن يؤكســـ أن التصــوف الر اشـــ الحـق هــو:

الإسلام، و ليس في الإســلام سـلبية، و لا تواكـل، و إنهـا هــي أمــر اض اجتهاعية لصقت بالتصـوف زورًا و بهتانًا، و لتأكيسـد ذــك فقـد راح يضرب أمثلة من التصوف العملـي التـي كانـت مثانًا لتجلـي الفعـل الصوفي في الواقع مثل:(عبد الله بن المبـارك) الذي كان يحـجِ عامــا و يجاهد عامًا، و (شقيق البلخي) الذي كان فارسًا مغوارًا، يطلب الهوت حتى استشهد في سبيل الله، و(أبو الحسن الشاذلي) الذي كان صـاحب مزارع و تجارة، وكان أيضـا مسن الـــين جهعـوا الهـريسـين لهـحاربــة الصليبيين في المنصورة، و (شمس الدين الدمياطي) الـذي بنـى بـرج

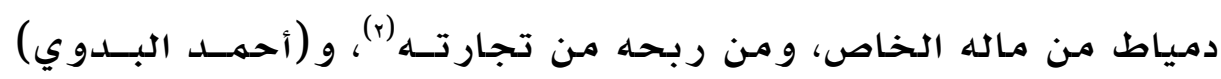

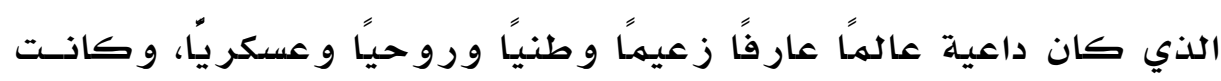
له مشاركاته الفعلية في الحروب الصليبية(r). و أكد أنه لو تتبعنا آداب الهريدين بالصوفية، لوجدناههم جميعًا

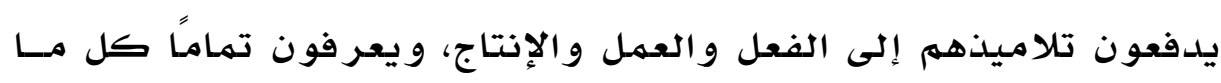
ورد في هذا الباب عن النبي (صلى الله عليه وسله)، ثم عـن أثـياخهم

(1) محمد زكي إبراهيم: الدليل إلى الطريقة المحمدية، ص: ه-؟.

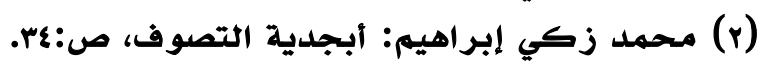

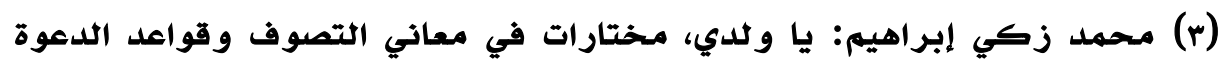

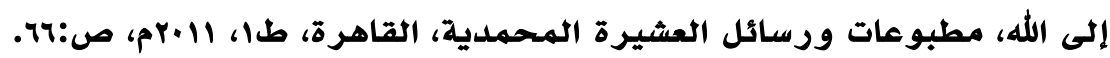
حولية كلية الآداب - جامعة بني سويف المئل 
في الله الذين يؤكدون لهم أنه لا يمكن تحقيق خلافة الله على الأرض بالسلبية والتواكل و الاستسلام. و أن التصوف ليس بأن تَصْفْ قدميك و غير ك يممون لك، و لكن ابدأ بر غيفيك فأحرز هما، ثـم تصسوف، ثـم اجعل منششارك مسبحتك، و اذكر على دقـات الفــأس والهكـولك. وقــد كانت الألقاب الصوفية تــدل علـى مـا يتناو لونـهـ مـن حسرف و مهـن

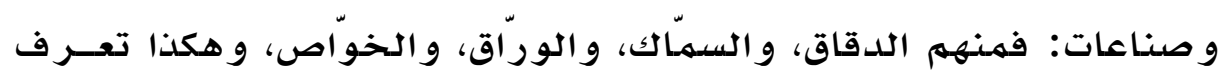

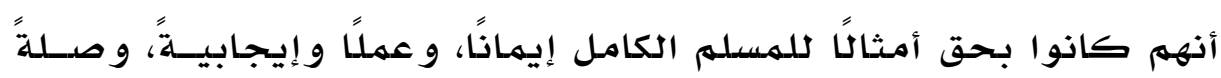
كبرى بالله. فالتواكل مـرض دخيل على التصـوف الصـحيح، يعالجـهـ صوفية العلماء، كلّ بأسلو بـه (1). و قد حاول زكي إبر اهيهم أن يُدخل هذه النظرة الإيجابيـة فـي كل أمور و آداب المتصوفة و أخلاقهم من خلال تأكيده على أن الفعل الصو في فعل حضاري، فر أى في فعل الخلوة أنه يساعد على الـتخلص من كافة الرو اسب و المشاغل و الشو اغل، و الههام و الهموم، و الانصر اف المطلق إلـى الله، والاسـتمداد مــن الطاقـة المقدسـة، لـتـخلص مـن المتاعب والإجهادات و المعايب المعنوية و العودة إلى مواجهة الحياة بما هي أهله من حيوية و فهم وطاقة ورشد، و نظافة و إنتاج حسي و معنوي، و ليس كما يفهمه المتحاملون نوع من الانطواء و السلبية و الضعف، أو الهروب مـن مواجهة مـرارة الــواق، وإنّهــا الخلــوة اسـتعداد وتــدريب (1) محمد زكي إبراهيم: أبجدية التصوف، ص:هr.

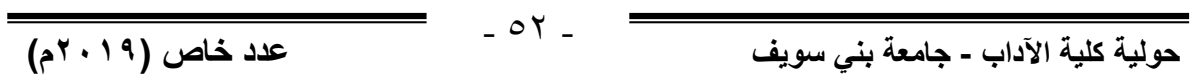


وتربيـة إيجـابيسة، وقـوة ومصسابرة ووكفـاح مـريـر، لا يعرفــه إلا

مهمار سوه (1)

فالخلوة إذن إحلىى و سـائل الهـحافظة على الكرامـة الإنسانية

و على الصحة الجسهية و النفسية، و على الهعـالم الدينيــة و الر وحيــة، و على المصسالح الوطنيـة و القوميـة و التقدميـة، و هكـذا ينكشـف للنــاس الهفهوم الواقعي الأصسيل كلكر امـة الإنسـانية والإسلاميلة فـي مسلدلولات التصوف الإسلامي ومسجاهداته، كلها عميت عليهم أو كلهما استعصدت بحكم الجهل و الهمادية(r)

أمـا علاقة الشـيخ بالهـريـد فهـي تأكيـد للكر امسـة و الكينونـة

الإنسـانية، حيث يرى إنه يجب على المـر يـ أن يبـحث عن الشيخ القـلدوة و المهعلم الهمربي كما بحث موسى عن الخضــر، ور غــم تأكيـده علــى

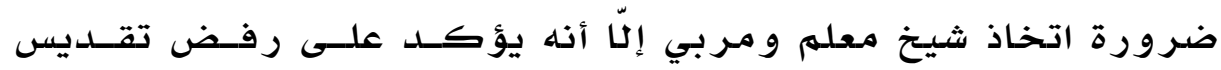

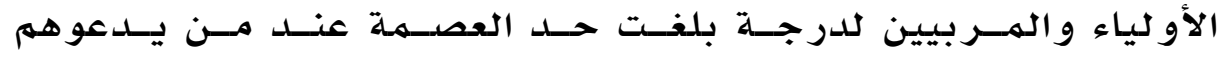
بالجهاء، و يرى في ذلك ذوعا مسـن الاسـترقاق و العبـوديـة و الاتجــار بالبشر، و إهدار الآدمية بعد إلغاء حكهم الشر يعة والحقيقـة و الطريقـة و الهعقو لية والتاريخ؛ الأمر الذي لا يقبله على نفسه إنسان يؤمسن بالله

(1) محمد زكي إبراهيم: أصول الوصول أدلة معالم الصوفية الحقة من صريح الكتاب و السنة، صو:4+1)

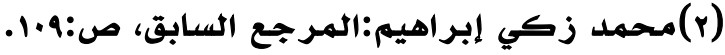
حولية كلية الآداب - جامعة بني سويف 
ورسو له، أو مسـلهم يحس بوجـوده وكر امتــه ورسـالته فـي الحيـاة(1) مؤكاًا على أن الشيخ مـا هو إلا دليل فقط (r)

وبالنسبـة كلاحتفال بالهوالد فذهب إلى أن الأصسل فـي إقامتهــا

هو الاعتبـار بسيرة صـاحب الهو لد، والانتفاع بذكر اه، وانتهاز فرصسة التجمـع للتعارف والتعـاون على البـر و التقــوى والانصــراف إلـى الله بذكره و التعبد له، و الاستماع إلى الوعظ و القر آن، و إخر اج الصسلدقات، و هي نوع من الشكر الجماعي لله تعالى على تفضله بهـن جعل ذكريات موالدهم هذه خيرًا على الهسلمين في دينهم ودنياهم. وهي مؤتمر ات لتدارس ثـئون الهسلمين محليًا و عالهيًا، فهـي أسـواق دينيــة جامعـة لمطالب العقول و القلوب بالإضـافة إلى تنشيط الحرركـة الاقتصسادية و الاجتمـاعية و الترو يحية النظيفة؛ و لهّا كان ذلك ندب الإسـلام إلـى هذه الخدمات المباركة، و لكل منها أدلّتها فهثلًا: الوعظ مطلوب شـرعا،

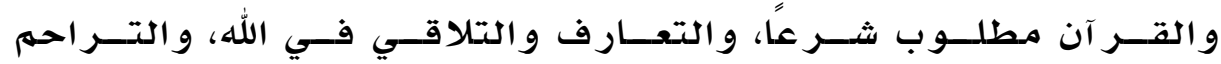
و التعاطف و التهادي و الحب، و إذا كانت أفـراد الشـيء مطلوبـة آحسـادا

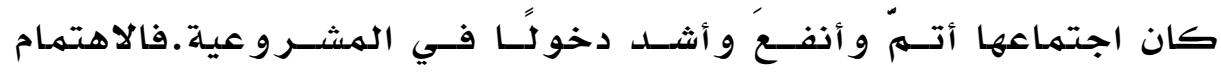
بالهو لد عند الشيخ الرائد يدخل في باب التاريخ و فلسـفة الحضـارة، فقد اهتمـت الأمـهم علـى اخــتلاف أديانهـا و عقائـدها بإحيـاء ذكريـات أبطالها الدينيين و المدنيين، بل و إحياء ذكريات أيامها الخوالد، لها في

(1) (1) (1) (17)

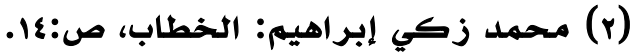
حولية كلية الآداب - جامعة بني سويف 
ذلك من التربية النفسية والتوجيه، وتركيز المبادئ والمذاهب التي تؤمن بها الأمهم. فإحياء هذه الذكريات المبـاركة سُّنّة إنسـانية مـن أصول طبـائع الأمسه، وضــرورة مــن ضــرورات المجتتهــع للتنفـيس، و التروويح المـحبب، و مناسبة ناجحة مـن مناسـبـات الانتعساش الثقـافي و التجاري و العلهي و الرووحي و الاجتمــاعي و النفســاني و غيـره، و لكـن بشرط الانضباط و عدم تأثير ذلك بشكل سلبي علـى الــدين وتشـويه

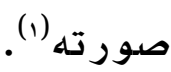

و لهم يكن تجلي الفعل في الواقــع عنــــ زكــي إبـر اهيهم مـجـرد

خطاب وسياحة عقلية، بل كان تجربة ومـمارسة فعليـة ، وقـــ كــان نهموذجًا في تطبيق ما آمـن بـه، جامعًا بـين النظـر و العهـل، وكــان نموذجًا لتطبيق فلسفة الفعل من منظوره الصـوفي، ــيس فقـ مـن خلال مجاهداته، وزهده، و أحواله، و مقامـاته الروحيسة، بـل أيضــا مسن خلال مؤسسة(العشيرة الهـحمدية) التي هي تجلي للفعل الصـوفي فـي الواقع الاجتماعي، فالعشيرة ليست فقط مجسر د تجمهّع لفعسل قـر اءة

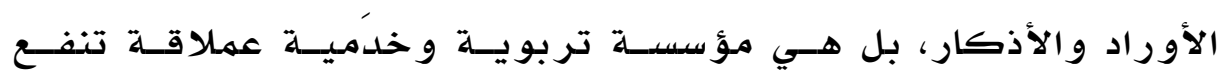
المجتهـع من خلال فروعها و مساجدها الهنتشرة في مصـر وخارجهـا، و من خلال بناء المستشفيات والمستوصفات الصحية، ومشاغل الفتيات، وحضانات الأطفال، ومـراكـز تأهيـل وتـــريب الثـبـاب علـى الحسـرف (1) محمد زكي إبراهيم : أصول الوصول أدلة معالم الصوفية الحقة من صريح

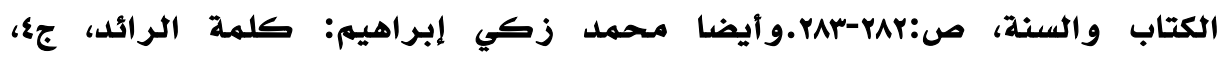
ص:PYY-rYI

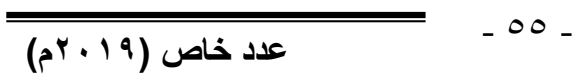


و الصناعات، وون خلال معهـد رواد التصــوف، والأكاديميـة العالميـة لدراسـات التصدوف التي تمنـح درجات الإجـازة و الليســانس، و الماجسـتير و الدكتور اه بإشـر اف الأزهـر، ومـركـز الدراســات الصــوفية، وومسلــة المسلهم، و مـجلــة البـحـوث و اللدراســات الصــوفية، و الهـؤتهـر الصــوفي العـالهي، وومن خلال الهـراكز الإسـلاميـة الجـامعة، والهـراكـز الطبيــة، كل ذلك يسري فيه آداب و أخلاق التصدوف من حب وتعاون وتســـح وترقي سلوكي، وقد كانت عين العشيرة دائمَّا علـى الهـــاطق التـي ينقصها الخــدمات، فيكسون الفعـل الصــوفي فيهـا دافعـا إلــى الترقـي و التحضر (1) •. وهكذا كــان مهحهـل زكـي إبـر اهيهم كهــا و صدف هـو الصدوفي الرباني بقو له: "هكذا يكون الصدوفي هو (الهسـلهم النهـوذجي)

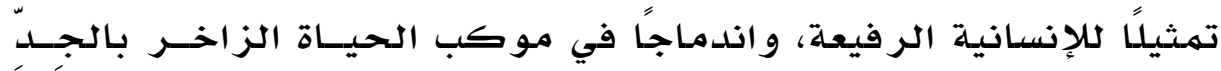
و المهجد، و العمل الروحي، و العهل الحضساري"(r). و هو بـلك يضيف حلقــة جديسـدة و مـجــددة لسلســة التصــوف

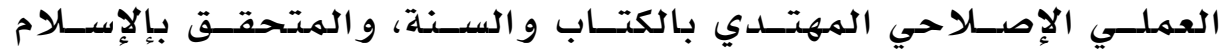
و الإيهمان و الإحسان، الذي أسهم في الحياة الإجتهماعية و العمليــة، وهــا مـا يكشفه لنـا التاريخ المنصف الذي يوثـق معانـاة أعلامسـه، و أدوارهـهم الإصلاححية وتفـردهم بـالتوجـهـ الروحسي، مثـل أبـو الحسـن الشــاذلي

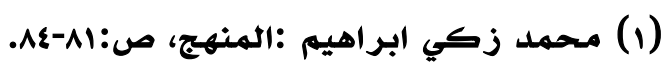

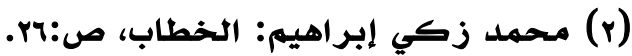
حولية كلية الآداب - جامعة بني سويف 
و تلهيذه أبو العباس الهـرسي(1) وحتــى أحهـــ الــدردير وعبــ القـادر

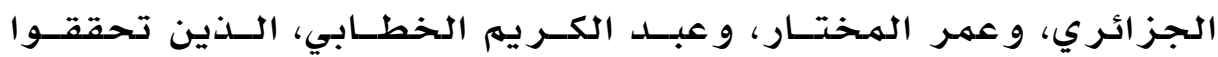
بالتصوف العملي الذي استممد أصسالته مسن الإســلام ، فصــح أن يكـون

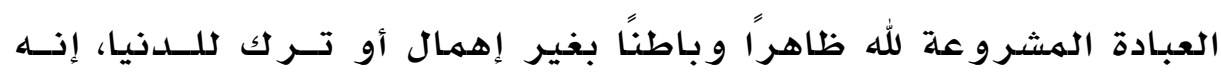
التصوف الذي يجعل الوقت الذي يبلغ فيه الإنســان مبلغًا رفيعًا فـي ترقية واقعه هو نفسـه الوقت الذي يتحقق فيسه بهقامــات القـرب مـن

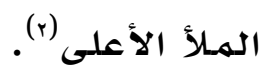

\section{الخاشمة:}

في ختام هذا البحث انتهى الباحث إلى أن الفعـل فـي التصـوف العملي عند محمد زكي إبر اهيم هدفه جعل رسـالة الصــوفي رسـالة إصلاحية إنسانية تتحقق في الهمارسة الحياتية بكل تجلياتهـا الدينيـة و السياسية و الاجتهماعية و الاقتصدادية و الحضارية. ومسن هـــه النقطــة يلتقي التصدوف بفلسفة الفعل التي تتمـحسور حــول الفعـل كمهمارسـة حياتية تؤكد الوجود الإنساني وتحققه في الواقع.

إن طبيعـة الفعل الصوفي عند محمدم زكي إبـر اهيم أنـه فعـل إصلاحي إيجابي في جوهره، لأنه لا يتحقـق إلا بالهمارسـة ومسن ثـم

(1) مجدي محمد إبراهيم: أبو العباس المرسي مذهبه و آراؤه الصوفية، دار الكتب

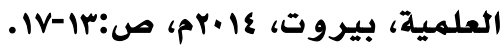

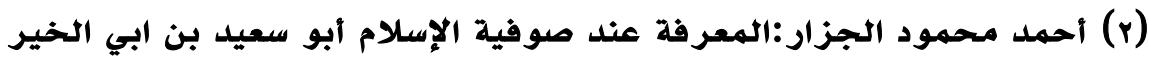

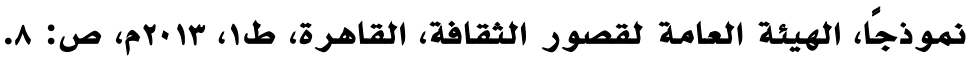

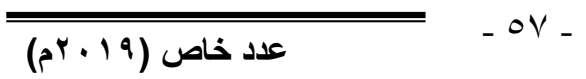
حولية كلية الآداب - جامعة بني سويف 
فالصوفي لا يكون ربـانيًا إذّا إذا أدى وظيفته نحو الخالق و الخلق حتىى تظهر آثار الفعل الصوفي في الواقع.

يتميز الفعل الصـوفي في التصوف العملي بعدد مـن الخصـائص

أو لها: أنه يبدأ مـن الداخل فيصلّح مـا بالنفوس، حتى يتهيأ لإصلاح مــا بالأكوان. و ثانيها: أن يعتهمد على التذوق القلبـي. وثالثها: أنسه فعـل منفتح لا يقف عند الإصلاحح الفردي بل يتعداه إلى الإصلاح الجمــاعي. ورابعها: أن الدافح الإصلاحي في الفعل الصدوفي يتأسسس علـى الحسب الذي يتجلى في الهـهارسـة الحيـاتية من خلال تأكيد السـلام، و التسـامح، و اللين، و التعاطف، وقبـول الآخــر • و نفـي العنـف، والقهـر ، والقســوة، و التعالي، و الخبث، و التغالي، و أذى الناس. و خامسها: أنه فعل إيجـابي فهو دعوة إلى القوة والعلمه، والعـزة، و العدالــة، و المســاو اة، و الإحيـاء، و التكافل، و التكامل، و التجديد، و الابتكار، و السيـادة، و القيـادة. استطاع محمدل زكي إبراهيهم أن يطبق خطابـه الصدوفي العملـي ورسـالته الإصدلاحية في أرض الواقع بدرجة كبيرة، والسبب في ذلك

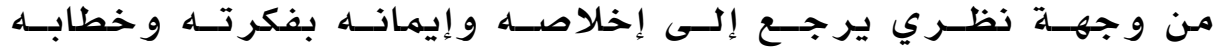

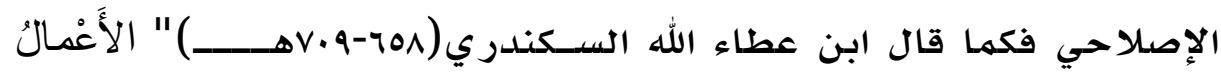

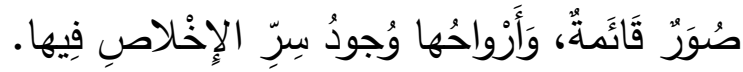




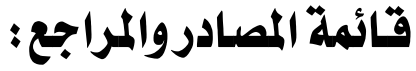

ا. أبو حامد الغزالي: أيها الولد: حققها و علق عليها: علـي محسي الدين على، دار البشائر الإسلامية، بيروت، ط\&، •.1. م.

r. أبو عبد الرحهن السُلهي: الطبقــات الصـوفية، تحقيـق: أحهـــ الشرباصي، مؤسسة دار الشعب، القاهرة، طب، 1991م.

r. أبو يزيد البسطامي: الأعمال الصوفية الكاملة، تحقيق وتقديه: قاسه محممد عباس، دار المدى ، دمشق، طا، ع.+.بم. ع. أحمد بن أحمد البرنسي(زروق):قواعد التصوف، ضبطه و علـق عليه: محمهود البيروني، دار البيروني، دمشق، طا، ع.بrم. 0. أحمد محهود الجزار :المعرفة عند صوفية الإسلام أبو سعيد بن ابي الخير نهوذجًا، الهيئة العامة لقصور الثقافة، القاهرة، طا، سا.بم. T. ايهاب عبد العزيز الكومي: الشيخ محمد زكي الدين إبـراهيم، وجهوده في التصوف، رسالة دكتـور اة، كليــة التربيسة جامعسة عسين

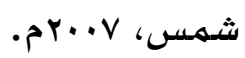

V. زكريا إبر اهيهم : فلسفة الفعسل، رسـالة مقدمسة لنيـل درجسة الماجستير في الآداب من قسهم الفلسفة، القاهرة، 19\$1م.

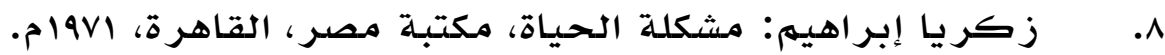


9. سعـاد الحكيهم: التصدوف يحقـق التقــارب بـين الهــذاهب، مـجلــة

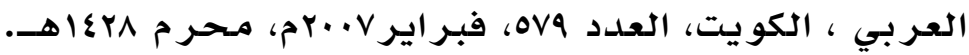

•l. سيد حافظ عبد الحميد: التصوف العملي و المشروع الحضاري عند عبد القادر الجزائري، الهيئة الهصـرية العـامـة للكتــاب، القـاهرة، $\cdot r r \cdot \ln$

ال. طه عبد البـاقي سرور: مـن أعسلام التصـوف الإسـلامي، مكتبـة نهضدة مصر و مطبعتها، القاهرة، د.ت.

rا. طه عبد الرحهن: سؤال العهل بحث عن الأصول العملية للفكـر و العلهم ، الهـركز الثقافي العربي الهغرب، بيروت: طا، rا•rم. سا. عبد القادر الجزائري: المواقف الروحية و الفيوضات السبهوحية، موقف ه00، جr، اعتنى بـه وقدم له: عاصهم إبر اهيهم الكيـالي، منشــورات محمد علي بيضدو، ودار الكتب العلميـة، بيروت، طاو ع.rم. ع ا. عزت قرني: الذات ونظريـة الفعل، دار قبــاء للطبـاعـة و النشـر

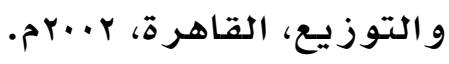

10. مجدي محهد إبــراهيه: أبـو العبـاس الهرسـي مذهبـه و آراؤه الصوفية، دار الكتب العلمية، بيروت، عا بrم.

17 . محهد زكي إبراهيه: الخطاب، علق عليه عبد الـر حمـن حسـن

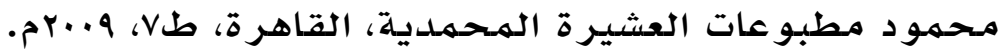


IV. محهد زكي إبر اهيهم: الدليل إلى الطريقة الهـحهديـة، مطــابع العشيرة الهحمدلية الشاذلية، القاهرة، طا، 1910ام.

1. محمد زكي إبراهيه: السلفيـة الهعاصرة إلى أين؟ ومـن هم أهل السنـة؟ قدم لها وعلق عليها محي الدين حسين الاسنوي، مؤسسة احيـاء

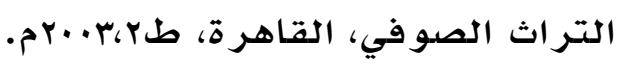

19. محمد زكي إبر اهيه: الهنهج، مطبوعـات العشـيرة الهحمديـة،

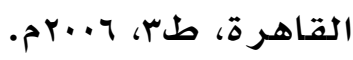
•r. محمد زكي إبـر اهيهم: ديـوان البقايـا، الجــزء الثــاني، الوابـل الصيب دلإنتاج و التوزيع و النشر، القاهرة، طب، · ·rم. اY. محهد زكي إبر اهيه: كلهــة الر ائسل، جr، مطبو عــات ورسـائل العشيرة الهـحمدية، القاهرة،طا، ه..r. م. Yr. محمد زكي إبر اهيهم: كلهــة الر ائلد، جع، مطبو عــات ورسـائل العشيرة المححمدية، القاهرة، طا، ب.rم.

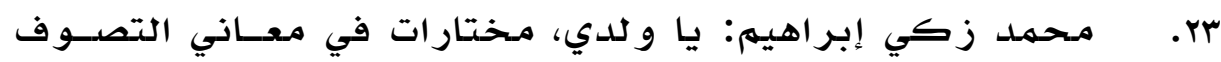
وقواعــد الــدعوة إلـى الله، مطبوعــات ورســائل العشـيرة الهـحمديــة،

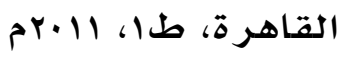

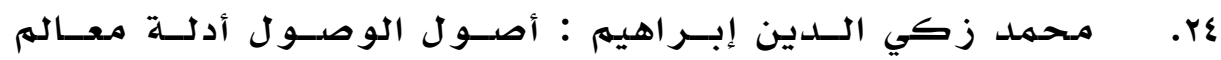
الصدوفية الحقة من صـريح الكتاب و الســنة، قـر اءة و أعتتـى بــه سـعيد المندوه، مطبوعات العشيرة الهـحمديـة، جا، طه، 0..rم. 
0. محي الدين بن عربي : الفتوحات الهكيــة، جr (نسـخة الأميـر

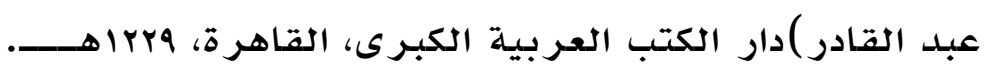

דr. محسي السـين بـن عربـي: الوصـايا: دار الإيهـان ، دمشـق، طץ، .1941

مV محي الدين بن عربي: فصوص الحكم، تحقيق أبو العلا عفيفي، دار إحياء الكتب العربيـة عيسـى البـابي الحلبـي وشــركاه، القـاهرة، . 1957

א Y. محي الدين حسين الإسنوي: الفهرست الجامع لهؤلفات شــيخنا الإمام الر ائد محمد زكـي إراهسـهم، مطبوعـات العشـيرة الهـحمديـة،

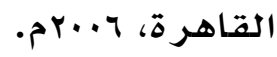

99. محي الدين حسين الإسنوي: ترجمة موجزة و تعريـف بفضـيلة الإمـام الر ائد، مطبوعات ورسائل العشيرة الهحمدية، القاهرة، ج+بrم. •r. هنري برجسون: التطور الخالق، ترجمة محمد محمود قاسـهم، الهركز القومي للتر جمهة، القاهرة، 10 +rم. 


\section{Annual of the Faculty of Arts}

A Refereed Academic Annual

Published by the Faculty of Arts . Beni -Suef University

Special Issue

2019 
International Standard Serial Number

ISSN $2314-8160$

URL : $\underline{\text { http://www.bsu.edu.eg/artsyearly/artsyearly.aspx }}$ Facebook:

https://www.facebook.com/groups/1453803511522941/?ref =bookmarks

Beni Suef University Center for Printing and Publishing 